\title{
1 Tracking the hydro-climatic signal from lake to sediment: a field study from central
}

\section{Turkey}

3

4 Jonathan R. Dean $^{\mathrm{a}^{*}}$, Warren J. Eastwood ${ }^{\mathrm{b}}$, Neil Roberts ${ }^{\mathrm{c}}$, Matthew D. Jones ${ }^{\mathrm{d}}$, Hakan

5 Yiğitbaşıoğlu ${ }^{\mathrm{e}}$, Samantha L. Allcock ${ }^{\mathrm{f}}$, Jessie Woodbridge ${ }^{\mathrm{c}}$, Sarah E. Metcalfe ${ }^{\mathrm{d}}$, Melanie J.

6 Leng $^{\mathrm{a}, \mathrm{g}}$

7

$8{ }^{a}$ NERC Isotope Geosciences Facilities, British Geological Survey, Nottingham NG12 5GG

$9 \quad U K$ jonathan.dean@bgs.ac.uk; mjl@nigl.nerc.ac.uk

$10{ }^{b}$ School of Geography, Earth and Environmental Sciences, University of Birmingham, B15

112 2TT UK $\underline{\text { w.j.eastwood@bham.ac.uk }}$

$12{ }^{c}$ School of Geography, Earth and Environmental Sciences, University of Plymouth, PLA 8AA

$13 U K \underline{\text { c.n.roberts@plymouth.ac.uk; jessie.woodbridge@plymouth.ac.uk }}$

$14{ }^{d}$ School of Geography, University of Nottingham, NG7 2RD UK

15 matthew.jones@nottingham.ac.uk; sarah.metcalfe@nottingham.ac.uk

16 e Department of Geography, Ankara University, Ankara, Turkey yigitbasioglu@gmail.com

$17{ }^{f}$ Faculty of Science and Technology, Bournemouth University, Poole BH12 5BB UK

18 sallcock@bournemouth.ac.uk

$19{ }^{g}$ Centre for Environmental Geochemistry, School of Geography, University of Nottingham,

$20 N G 72 R D U K$

21

$22 *$ Corresponding author, email: jonathan.dean@bgs.ac.uk, phone +44 (0) 7944747013 


\section{Abstract}

24

25 Palaeo-hydrological interpretations of lake sediment proxies can benefit from a robust 26 understanding of the modern lake environment. In this study, we use Nar Gölü, a non-outlet,

27 monomictic maar lake in central Turkey, as a field site for a natural experiment using

28 observations and measurements over a 17-year monitoring period (1997-2014). We compare

29 lake water and sediment trap data to isotopic, chemical and biotic proxies preserved in its

30 varved sediments. Nar Gölü underwent a 3 m lake-level fall between 2000 and 2010.

$31 \delta^{18} \mathrm{O}_{\text {lakewater }}$ is correlated with this lake-level fall, responding to the change in water balance.

32 Endogenic carbonate is shown to precipitate in isotopic equilibrium with lake water and there

33 is a strong relationship between $\delta^{18} \mathrm{O}_{\text {lakewater }}$ and $\delta^{18} \mathrm{O}_{\text {carbonate, }}$ which suggests the water balance

34 signal is accurately recorded in the sediment isotope record. Over the same period,

35 sedimentary diatom assemblages also responded, and conductivity inferred from diatoms

36 showed a rise. Shifts in carbonate mineralogy and elemental chemistry in the sediment record

37 through this decade were also recorded. Intra-annual changes in $\delta^{18} \mathrm{O}_{\text {lakewater }}$ and lake water

38 chemistry are used to demonstrate the seasonal variability of the system and the influence this

39 may have on the interpretation of $\delta^{18} \mathrm{O}_{\text {carbonate. }}$ We use these relationships to help interpret the

40 sedimentary record of changing lake hydrology over the last 1,725 years. Nar Gölü has

41 provided an opportunity to test critically the chain of connection from present to past, and its

42 sedimentary record offers an archive of decadal- to centennial-scale hydro-climatic change.

43

44 Keywords: Oxygen isotopes, Diatom analysis, Lake sediments, Monitoring, Seasonality,

45 Carbonates

46

47 


\section{$48 \quad$ Highlights}

49

50 - Study of non-outlet, oligosaline, varve-forming lake in a semi-arid region

51 - Water balance signal in oxygen isotopes tracked from lake waters to sediments

52 - Strong intra- and inter-annual relationships between isotopes and water balance

53 - Diatom-inferred conductivity shows a complex response to change in water balance

54 - Implications of monitoring data for interpretation of palaeo-records 


\section{1. Introduction}

56

57 In order to use lake sediments to reconstruct past climate change reliably, it is vital to 58 understand the modern hydrology of the study site (e.g. Hollander and McKenzie, 1991; Leng 59 et al., 1999; Saros, 2009) and to be able to track this signal to the sediments. Lake systems

60 respond to hydro-climatic variations via a number of linked parameters, including lake

61 volume, salinity concentrations and the oxygen isotope $\left(\delta^{18} \mathrm{O}\right)$ composition of waters. Non-

62 outlet lakes respond particularly dynamically to changes in water balance (Leng and

63 Marshall, 2004 and references therein); with increased evaporation, water volume decreases,

64 salts become concentrated and $\delta^{18} \mathrm{O}_{\text {lakewater }}$ becomes more positive, and vice-versa, although

65 parameters may be subject to hysteretic effects (Langbein, 1961) as well as other factors such

66 as saline groundwater inflows.

67 Limnological parameters such as water balance are registered by proxies preserved in

68 lake sediments, which in turn permit the reconstruction of lake hydrology for pre-

69 instrumental time periods (Fritz, 2008 and references therein). Past water level fluctuations

70 can be reconstructed via dated lake marginal depositional facies, such as shoreline terraces

71 and carbonate platforms (Magny, 2006), and by changes in the species assemblages and life

72 forms of diatoms and other biological indicators (e.g. Barker et al., 1994). Salinity inferred

73 from biological indicators, such as diatom and ostracod assemblages, is sometimes quantified

74 as variability in electrical conductivity (EC) based on transfer function techniques using a

75 modern training set (e.g. Fritz et al., 2010; Reed et al., 2012). Past salinity levels can also be

76 reconstructed semi-quantitatively from elemental chemistry ratios such as $\mathrm{Ca} / \mathrm{Sr}$ and $\mathrm{Mg} / \mathrm{Ca}$

77 (Ito, 2001). In many lakes, the form of carbonate precipitated from lake waters shifts from

78 low-Mg calcite in dilute lake waters to high-Mg calcite or aragonite in more saline lake

79 waters (Kelts and Hsü, 1978) and the $\mathrm{Ca} / \mathrm{Sr}$ ratio can decrease if there is a shift from calcite 
80

81

82

83

84

85

86

87

88

89

90

91

92

93

94

95

96

97

98

99

100

101

102

103

104

to aragonite precipitation (Tesoriero and Pankow, 1996). Stable isotopes can also be used as a palaeo-hydrological proxy: lake water $\delta^{18} \mathrm{O}$ is recorded in carbonates that precipitate in lake water; $\delta^{18} \mathrm{O}_{\text {carbonate }}$ is also modified by temperature and potentially by disequilibrium or diagenetic effects (Leng and Marshall, 2004 and references therein).

Limnological sampling, monitoring and observation can provide fundamental insights into all of the processes described above, and therefore strengthen the interpretation of lake sediment records. Monitoring of lake levels leads to an understanding of the sensitivity of a given lake to hydrological and/or climatic change. Recording biological response to measured climate or hydrological change improves the interpretation of downcore species changes.

Monitoring data may be especially important when using stable isotopes as a hydro-climatic proxy because it is not possible to apply modern analogue or transfer function techniques, substituting time with space, to these records due to their dependence on multiple climatic and site-specific non-climatic variables (Tian et al., 2011). Monitoring allows the establishment of the key drivers of $\delta^{18} \mathrm{O}_{\text {lakewater in the lake being studied and a better }}$ understanding of how the signal is transferred to carbonates in the sediment record. Such a monitoring approach can provide a basis for judging which proxies provide the most reliable register of environmental changes (such as hydro-climate) and why different proxies can show different trends in the palaeo-limnological record, although the possibility that present lake states are not good analogues for the past should also be considered.

There are logistical and financial barriers to collecting modern data and samples over multiple years and different seasons for a length of time suitable to ensure robust proxy interpretation, especially in remote regions. However, in this study, we have been able to collect a substantial number of samples from Nar Gölü (göl = lake in Turkish), a small, hydrologically sensitive maar lake in central Turkey, over a period of 17 years (1997-2014). Although our monitoring and observational data are far from complete, they do allow an 
105 assessment to be made of both seasonal variations and multi-year trends. If lake sediments

106 are sufficiently well resolved in time, it is possible to trace changes measured from lake

107 waters collected from certain years to the sediments that correspond to that year. Nar Gölü is

108 particularly useful for such an exercise because the sediment record is annually laminated

109 (varved). We have therefore been able to correlate, with high precision, monitoring and

110 instrumental climate data to palaeo-limnological information from the sediment cores over

111 the same period.

112 The study lake was subject to a progressive water level decrease between 2000 and

113 2010. We examine how this change in lake water balance was registered by different hydro-

114 chemical and biological parameters over time, and how they were subsequently incorporated

115 in the contemporaneous lake sediment record. Some neo-limnological data from Nar Gölü

116 have been previously published: Jones et al. (2005) compared modelled and measured $\delta^{18} \mathrm{O}$

117 results (using water isotope data from 1999-2002) and Woodbridge and Roberts (2010)

118 examined diatom assemblage data (with contemporary samples taken 2002-2007). Here we

119 present new water isotope and chemistry data to extend the record up to 2014 and new

120 sediment isotope and diatom assemblage data to bring the record up to 2010. With this longer

121 time series of monitoring data, we build on these previous studies and aim to: (1) establish

122 the general physical, isotopic and geochemical characteristics of the lake, (2) scrutinise intra-

123 annual trends in lake water chemistry and $\delta^{18} \mathrm{O}_{\text {lakewater }}$ to understand the seasonal variability of

124 the system, (3) compare inter-annual variability in lake water chemistry and $\delta^{18} \mathrm{O}_{\text {lakewater }}$ to

125 physical and climate variables in order to test the drivers of the record, and (4) compare these

126 data to isotopic, biological and geochemical proxies from the sediment record. The analysis

127 of modern limnology and the tracking of signals from the lake water to sediments from the

128 last decade allow us to assess critically individual palaeo-limnological proxies at Nar Gölü, 
129 ultimately to better interpret the long-term sediment record of Holocene hydro-climatic

130 change (e.g. Jones et al., 2006; Woodbridge and Roberts, 2011; Yiğitbaşığlu et al., in press).

131

\section{2. Site description}

133

134 Nar Gölü $\left(38^{\circ} 20^{\prime} 24^{\prime \prime} \mathrm{N}, 34^{\circ} 27^{\prime} 23\right.$ "E; 1,363 m.a.s.l.) is a small $\left(\sim 0.7 \mathrm{~km}^{2}\right)$ but relatively deep

135 (>20 m) maar lake in Cappadocia, central Turkey (Figure 1). It is oligosaline, alkaline and

136 predominately groundwater-fed, with a residence time of 8-11 years (Jones et al. 2005;

137 Woodbridge and Roberts, 2010). The crater geology is predominately basalt and ignimbrite

138 (Gevrek and Kazanc1, 2000). Nar Gölü lacks any surface outflow. At its southern edge there

139 are a series of small inflowing ephemeral stream channels forming an alluvial fan, and the

140 bathymetric map (Figure 1) shows that this extends into the lake as a fan-delta.

141 The climate of the region is continental Mediterranean (Kutiel and Türkeş, 2005) with

142 annual precipitation at Niğde, $45 \mathrm{~km}$ from Nar Gölü and 1,208 m.a.s.l., averaging $339 \mathrm{~mm}$

143 from 1935 to 2010 . Mean monthly temperatures $1935-2010$ varied from an average of $+23^{\circ} \mathrm{C}$

144 in July and August to $+0.7^{\circ} \mathrm{C}$ from December to February (see Dean et al., 2013 for more

145 detailed regional climate data).

146 Although the lake watershed contains no permanent dwellings and only a few

147 agricultural fields, Nar Gölü has not entirely escaped human impact. Firstly, groundwater

148 pumping for irrigation in the valley below the lake is likely to have steepened the hydraulic

149 gradient in recent decades, possibly increasing groundwater outflows from the lake.

150 Secondly, in 1990 the Turkish Geological Survey (MTA) drilled boreholes near to the lake to

151 reach artesian geothermal groundwaters (Akbaşl1, 1992). Oral testimony indicates that one of

152 these drill holes significantly disturbed lake hydrology and ecology (potentially including a

153 breakdown in lake stratification and a decrease in the population of aquatic macrophytes), 
154 probably for several years, for which there is some evidence in lake sediment cores.

155 Consequently, and given the lake residence time, we restrict our analysis of changing lake 156 conditions to the period since 1997.

157

158 Figure 1

159

160 3. Materials and methods

161

$162 \quad 3.1 \quad$ Fieldwork

163

164 Water samples were collected from the lake during 22 field visits between 1997 and 2014.

165 When conditions permitted, depth profiles were taken from the deepest part of the lake

166 through the water column using a Van Dorn bottle (Van Dorn, 1956) or a Glew corer (Glew

167 et al., 2001) with temperature, $\mathrm{pH}$ and EC measured at the time on a Myron ${ }^{\circledR}$ meter.

168 Maximum lake depths were estimated using a Garmin Fish Finder $₫$ and a weighted tape and

169 checked against water level stage readings at the lake edge when possible. Bathymetry was

170 measured using a Boomer system coupled with a high precision GPS, based on 53 transect

171 lines north-south and east-west (Smith, 2010), in order to identify a suitable coring site.

172 Samples were taken for isotope and major ion analysis in the UK. Surface water samples

173 were taken in bottles initially washed three times in the sample, at $0.5 \mathrm{~m}$ depth to remove any

174 direct effects of exchange with the atmosphere. Where it was not possible to go out on the

175 lake, surface samples were taken from the same spot on the edge of the lake. Edge samples

176 were also taken by members of the local community between February and June 2012, as

177 well as a photo diary that allowed us to establish when snowmelt occurred that year (SI

178 Figure 1). Spring waters from the catchment (Figure 1) were also regularly sampled. 
179 Simple sediment traps, consisting of cylindrical plastic tubes under funnels, were

180 attached at a variety of depths onto ropes that were secured with an anchor on the lake bed

181 and a float on the surface and replaced every year. Since 2010, Tinytag ${ }^{\circledR}$ temperature

182 loggers have been attached to the sediment trap lines at a number of depths through the water 183 column. These provide temperature measurements at 20-minute intervals throughout the year.

184 A $44 \mathrm{~cm}$ long sediment core, which covers all but the last few years of the period of

185 lake water monitoring, was taken in 2010 (NAR10) using a weighted stationary piston corer,

186 another having been taken with a Glew corer $(36 \mathrm{~cm})$ in 2006 (NAR06). Longer cores

187 spanning 1,720 years were taken in 2001/2 (NAR01/02).

188

\section{$189 \quad 3.2 \quad$ Laboratory analyses}

190

191 Water samples were analysed for $\delta^{18} \mathrm{O}$ and $\delta \mathrm{D}$ on a VG Isoprime mass spectrometer and a

192 EuroPyrOH analyser. Isotopic ratios are given as \%o deviations from VSMOW, and analytical 193 reproducibility was $0.05 \%$ for $\delta^{18} \mathrm{O}$ and $2 \%$ for $\delta \mathrm{D}$. Major ion concentrations were measured

194 on water samples as soon as possible after returning from the field on a Metrohm ion

195 chromatography system. Data were converted from milligrams/litre to milliequivalents/litre $196\left(\mathrm{meqL}^{-1}\right)($ Hem, 1970).

197 Carbonates from sediment traps and core sediments were analysed for $\delta^{18} \mathrm{O}$ using an 198 offline extraction technique and a VG Optima mass spectrometer and data are given as \%o 199 deviations from VPDB, with an analytical reproducibility of $0.1 \%$. Carbonate mineralogy 200 was investigated by X-ray diffraction. The scanning range used was $5-65^{\circ} 2 \theta$ and the scan 201 rate was $2^{\circ} 2 \theta$ per minute with a step size of 0.05 . The TRACES program by Diffraction 202 Technology was used to identify which minerals were present. Where two or more minerals 203 were present, the proportions of each were determined by calculating the area under the peaks 
204 and the percentage of aragonite compared to calcite was estimated from experimentally

205 calibrated conversion curves (Hardy and Tucker, 1988).

206 X-ray fluorescence (XRF) analysis of elemental sediment chemistry was carried out

207 on split half cores by a field portable XRF spectrometer, which produces one single

208 dispersive energy spectra for each $3 \mathrm{~mm}$ sampling point on the core surface, with data in

209 parts per million.

210 Diatom samples were prepared using standard methods adapted from Battarbee et al.

211 (2001), described in detail in Woodbridge and Roberts (2010).

212

$213 \quad 3.3 \quad$ Numerical analyses

214

215 To model aragonite precipitation dynamics in Nar Gölü, the palaeo-temperature equation of

216 Kim et al. (2007) is used:

217

$218 \mathrm{~T}=(17.88 * 1000) /\left(1000 * \mathrm{LN}\left(\left(1000+\delta^{18} \mathrm{O}_{\text {aragonite }}\right) /\left(1000+\delta^{18} \mathrm{O}_{\text {lakewater }}\right)\right)+30.77\right)-273.15$

219

220 where $\delta^{18} \mathrm{O}_{\text {aragonite }}$ and $\delta^{18} \mathrm{O}_{\text {lakewater }}$ are expressed against VSMOW and $\mathrm{T}$ in ${ }^{\circ} \mathrm{C}$.

221

222 To model calcite precipitation dynamics, the palaeo-temperature equation of Hays and

223 Grossman (1991) is used:

224

$225 \mathrm{~T}=15.7-4.36 *\left(\delta^{18} \mathrm{O}_{\text {calcite }}-\delta^{18} \mathrm{O}_{\text {lakewater }}\right)+0.12 *\left(\delta^{18} \mathrm{O}_{\text {calcite }}-\delta^{18} \mathrm{O}_{\text {lakewater }}\right)^{2}$

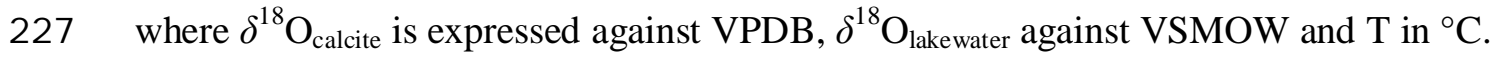


229 Diatom data have been used to infer EC using a combined salinity training set

230 (comprising data from East Africa, North Africa and Spain) provided by the European

231 Diatom Database (EDDI) (Juggins, 2014). Training sets and models were selected based on

232 the percentage of fossil sample species represented in the modern data set, the number of sites

233 in which these species are present and the model performance ( $r$ and RMSEP), and the

234 models were run using C2 software (Juggins, 2003). The combined salinity EDDI modern

235 training set was identified as possessing the highest number of matching analogue diatom

236 species in the Nar Gölü fossil assemblage (74.4\%; species not in the training set include

237 Clipeoparvus anatolicus, a species endemic to Nar Gölü; Woodbridge et al., 2010). Weighted

238 averaging with inverse deshrinking was identified as the model with highest predictive ability $239(r=0.85)$ and lowest prediction errors $($ RMSEP $=0.47)$. Detrended Correspondence Analysis

240 (DCA) was also applied to the diatom percentage data because the length of the axis was $>2$

241 units (Lepŝ and Ŝmilauer, 2003).

242 Monthly instrumental meteorological data from a nearby station at Niğde (155 m

243 altitudinal difference, $45 \mathrm{~km}$ from Nar Gölï) have been used to create a hydro-climatic index

244 of moisture availability (precipitation/evaporation; P/E). Because of the 8-10 year residence

245 time of the lake water (Jones et al., 2005), we calculated a cumulative weighted 8-year P/E 246 index.

247

248 4. Results

249

$250 \quad 4.1 \quad$ Basic limnological and sedimentological information

251

252 EC and major ion data show that the lake is oligosaline, with a mean conductivity value over

253 the past 15 years of $3,270 \mu \mathrm{Scm}^{-1}$ (Tables 1 and 2) and $\delta^{18} \mathrm{O}_{\text {lakewater values that are higher than }}$ 
254 freshwater $\delta^{18} \mathrm{O}_{\text {spring }}$ values (Figure 2), indicating that the lake waters are evaporated relative

255 to spring waters. A former lake high-stand is evident from carbonate-encrusted rocks and

256 strandline deposits, surveyed at $5 \mathrm{~m}$ above the 2010 water level, or $2 \mathrm{~m}$ above the lake

257 elevation in 2000, and provides physical evidence of the tendency of the lake level to

258 fluctuate. The sediments of Nar Gölü comprise alternating organic and carbonate layers

259 (varves; Ojala et al., 2012), with an organic and carbonate couplet shown to represent one

260 year of sedimentation based on analysis of sediment traps, thin sections and independent

261 dating of the sediment cores by ${ }^{210} \mathrm{~Pb}$ and ${ }^{137} \mathrm{Cs}$ (Jones et al., 2005; Woodbridge and Roberts,

262 2010).

263

264 Figure 2

265

266 Tables 1 and 2

267

$268 \quad 4.2 \quad$ Intra-annual variability

269

270 Figure 3 shows the intra-annual variability in water chemistry from samples taken

271 between June 2011 and July 2012. Within the data available, $\delta^{18} \mathrm{O}_{\text {lakewater }}$ values peak at -

$2720.13 \%$ in mid-September 2011 before falling to $-1.76 \%$ in mid-March 2012 and then

273 increasing to $-0.39 \%$ in mid-July 2012. EC values also peak in mid-September 2011 at 3,540

$274 \mu \mathrm{Scm}^{-1}$, before decreasing to $2,190 \mu \mathrm{Scm}^{-1}$ in late February 2012 (when there was heavy

275 snowfall and partial lake icing) and increasing again to $3,500 \mu \mathrm{Scm}^{-1}$ by July 2012 . pH values

276 decreased from 8.1 in June 2011 to 7.3 in February 2012 before increasing to 8.0 by June

277 2012. Magnesium concentrations decreased from $9.3 \mathrm{meqL}^{-1}$ in September 2011 to a

278 minimum of $3.2 \mathrm{meqL}^{-1}$ in late February 2012 and then increased to $16.5 \mathrm{meqL} \mathrm{L}^{-1}$ by July 
2792012 , whereas calcium concentrations showed the opposite trend, shifting from $2.2 \mathrm{meqL}^{-1}$ in

280 June 2011 to 4.0 meqL $L^{-1}$ in late February 2012 to 1.2 meqL $L^{-1}$ in July 2012.

281 Because the lake is monomictic, depth profiles, as well as surface samples, were

282 taken. In the summer, the waters of Nar Gölü are thermally and isotopically stratified, with

283 warmer and isotopically more positive waters in the epilimnion, followed by a shift at $\sim 7 \mathrm{~m}$

284 to colder and isotopically more negative values in the hypolimnion (Figure 4). The degree of

285 stratification becomes more pronounced from the spring to summer. While no depth profiles

286 were taken during the autumn or winter at Nar Gölü, temperature loggers show that the lake

287 is thermally mixed between November and March, with the same temperatures at $5 \mathrm{~m}$ and 21

288 m during the winter and then diverging in the spring (Figure 3 for 2011-12, but also observed

289 for other years; Eastwood et al., unpublished data).

290

291 Figure 3

292

293 Figure 4

294

295

4.3 Inter-annual trends

296

297 When considering inter-annual trends, samples collected from the same time of year

298 over multiple years are used to remove possible issues caused by the significant intra-annual

299 variability in the system presented in section 4.2. July is the month for which most data are

300 available. Samples from the lake centre are considered most representative of overall lake

301 conditions, because shallow water edge samples may be more affected by evaporation,

302 particularly in summer months. Nonetheless, the difference between centre and edge

$303 \delta^{18} \mathrm{O}_{\text {lakewater }}$ samples is only $\pm 0.3 \% \circ(1 \sigma, \mathrm{n}=4)$ in years where both were taken, which is small 
304 considering the size of the inter-annual isotopic shifts seen in the record. Therefore, edge

305 samples from 2000 and 2005 have been combined with centre samples from other years to

306 provide a more complete record. As Figure 5 shows, $\delta^{18} \mathrm{O}_{\text {lakewater }}$ values increased from -

$3073.20 \%$ in July 2000 to $-0.24 \%$ in July 2010 . Over this period, the lake level fell by

308 approximately $3 \mathrm{~m}$ and lake water volume shrank by $20 \%$. Measured July surface EC values

309 increased from 3,300 $\mu \mathrm{Scm}^{-1}$ in 2001 to $3,500 \mu \mathrm{Scm}^{-1}$ in 2012 (Figure 5), while lake surface

$310 \mathrm{pH}$ from the same month rose from $~ 7.5$ in 2001 to $>8$ in 2008 , before declining to 7.8 by

3112012 (Table 1).

312 The $\delta^{18} \mathrm{O}_{\text {lakewater }}$ increase for the period 2000-2010 was matched by an increase in

313 sediment core $\delta^{18} \mathrm{O}_{\text {carbonate }}$ values from $-3.7 \%$ o to $-0.5 \%$. There is a close relationship between

314 sediment trap and core $\delta^{18} \mathrm{O}_{\text {carbonate }}$ values from the same years, with both showing an increase

315 over the period of study (Figure 5). Sediment trap samples collected from different depths in

316 the same years (2002 and 2004) have $\delta^{18} \mathrm{O}_{\text {carbonate }}$ values that are the same within analytical

317 reproducibility. There are small differences between sediment trap and core $\delta^{18} \mathrm{O}_{\text {carbonate }}$

318 values from 2003, 2004 and 2005 but the trends are the same in both data sets. Between 2006

319 and 2007 there was a start of a trend towards a reduction in the $\mathrm{Ca} / \mathrm{Sr}$ ratio and a shift from

320 calcite to aragonite in lake sediment carbonates (Figure 5).

321

322 Figure 5

323

324 EC inferred from sedimentary diatom assemblages (diatom-inferred electrical

325 conductivity; DI-EC) underestimates modern measured lake EC (Figure 6) (reasons for this

326 will be proposed in sections 5.2 and 5.3, partly related to the fact C. anatolicus is not

327 included in the modern training set), but DI-EC trends do broadly match those from

328 measurements taken during the monitoring period. A change in sedimentary diatom 
329 assemblages began earlier than the DI-EC increase, with C. anatolicus and Synedra acus

330 replacing Nitzschia paleacea as the dominant taxa after 2001 (Figure 6).

331

332 Figure 6

333

334 The closest meteorological station to Nar Gölü with a long-term data set is at Niğde.

335 Annual precipitation in this area was at or below the long-term average $(339 \mathrm{~mm})$ from 1997

336 to 2008 , with the exception of 2001 . In addition, the 1990 s saw a significant $\left(>3^{\circ} \mathrm{C}\right)$ rise in average summer temperatures (Turkish State Meteorological Service, pers. comm).

338

\section{5. Discussion}

340

\section{$341 \quad 5.1 \quad$ Intra-annual variability at Nar Gölü}

342

343 The seasonal variability in surface water $\delta^{18} \mathrm{O}$ and conductivity shown in Figure 3 can be

344 explained by two main factors. Firstly, the water in the lake as a whole has lower $\delta^{18} \mathrm{O}$ in the

345 autumn, winter and spring, as these are the main seasons for rainfall and snowfall, input of

346 which will lower $\delta^{18} \mathrm{O}_{\text {lakewater }}$ (Dean et al., 2013). Although not quantified, observational data

347 show that lake levels were visibly higher in the spring than during the following summers.

$348 \delta^{18} \mathrm{O}_{\text {lakewater }}$ in 2012 was lowest in mid-March and the photo diary (SI Figure 1) shows this

349 was the time in that year of snowmelt from the catchment. Rainfall is also greatest in the

350 spring (Kutiel and Türkeş, 2005). Secondly, stratification of lake waters in the summer leads

351 to more positive $\delta^{18} \mathrm{O}$ values in surface waters than at depth because the hypolimnion is

352 unaffected by evaporative processes. Comparison of the depth profiles from April, June, July

353 and September (Figure 4) show that the isocline becomes more enhanced as the year 
354 progresses, with a $1.00 \%$ difference between surface and bottom water $\delta^{18} \mathrm{O}$ values in

355 September 2011 compared to a 0.75\%o difference in July 2010, 0.24\%o in June 2011 and $3560.23 \%$ in April 2013.

357 Given the seasonal variability in $\delta^{18} \mathrm{O}_{\text {lakewater, we need to establish the timing of }}$ 358 carbonate precipitation to allow for proper interpretation of the palaeo-record. Carbonate 359 precipitation in surface waters is demonstrated by the observation that sediment traps at $5 \mathrm{~m}$ 360 depth are encrusted in carbonate when changed each year, whereas deeper ones are not.

361 Variability in $\delta^{18} \mathrm{O}_{\text {carbonate }}$ with depth in one of the sediment traps suggests carbonate

362 precipitation under changing temperatures and/or $\delta^{18} \mathrm{O}_{\text {lakewater }}$ (Figure 7), i.e. that carbonate

363 precipitation occurs at different times of the year. However, $\delta^{18} \mathrm{O}_{\text {carbonate }}$ measured in the 364 sediment record from a whole-year varve will be weighted towards the time of maximum 365 precipitation. Observations suggest this occurs between May and early July. Firstly, in July, 366 calcium values at the surface are lower than at depth, suggesting draw-down of calcium 367 carbonate from the surface waters (Reimer et al., 2009), whereas in April 2013 calcium 368 concentration was still higher in surface waters than at depth, suggesting this draw-down had 369 yet to occur (Table 2). Secondly, analysis of the stratigraphy of Nar Gölü sediment traps 370 collected in July shows carbonate deposited on top of organic matter, while sediment traps

371 collected in April show organic matter on top of carbonate (Figure 8), suggesting that the

372 carbonate for that year had yet to precipitate.

373

374 Figure 7

375

376 Figure 8

377 
Additionally, it is possible to run Eqs. 1 and 2 using various $\delta^{18} \mathrm{O}_{\text {lakewater }}$ and

379 temperature scenarios, and then to compare the calculated equilibrium $\delta^{18} \mathrm{O}_{\text {carbonate }}$ values

380 from these equations to measured $\delta^{18} \mathrm{O}_{\text {carbonate }}$ from the sediment core. By seeing where the

381 calculated values match the measured values, it is possible to investigate better the timing of

382 carbonate precipitation. Before doing this, equilibrium precipitation and a lack of diagenetic

383 effects need to be demonstrated. It is not unknown for carbonate to precipitate out of

384 equilibrium with lake waters (Fronval et al., 1995; Teranes et al., 1999). During the July 2012

385 field season, carbonate in the form of aragonite was seen precipitating from the waters in a

386 'white-out' event (as seen in other lakes; Romero-Viana et al., 2008; Sondi and Juracic, 2010;

387 Viehberg et al., 2012) around the edges of the lake (SI Figure 2). Comparison of the

$388 \delta^{18} \mathrm{O}_{\text {carbonate }}$ value from this aragonite precipitate $(-1.3 \%)$ to the $\delta^{18} \mathrm{O}_{\text {carbonate value predicted }}$

389 using Eq. $1\left(-1.8 \%\right.$, using the $\delta^{18} \mathrm{O}_{\text {lakewater }}\left(-0.39 \%\right.$ ) and temperature $\left(+25.6^{\circ} \mathrm{C}\right)$ values

390 measured from a water sample taken at the same time), show that it formed in equilibrium

391 within analytical and equation error. Diagenesis may alter the carbonate isotope signal

392 between precipitation and deposition (Teranes and Bernasconi, 2000). However, at Nar Gölü,

393 there are only small differences between the $\delta^{18} \mathrm{O}_{\text {carbonate }}$ values of trap and core sediments

394 from the same year (Figure 5) and the inter-annual trends are very similar, which suggests

395 minimal alteration of the $\delta^{18} \mathrm{O}_{\text {carbonate }}$ signal during and after deposition.

396 Based on the observations already outlined, we assume that most carbonate is

397 precipitated sometime after April but before the end of July and in surface waters. Therefore,

398 we use likely surface water temperature and $\delta^{18} \mathrm{O}_{\text {lakewater values from May to July to calculate }}$

399 potential $\delta^{18} \mathrm{O}_{\text {carbonate }}$ values. Temperatures vary from year to year, but temperature loggers

400 suggest temperatures change from $\sim+12.5^{\circ} \mathrm{C}$ in the beginning of May to $\sim+17.5^{\circ} \mathrm{C}$ in mid-

401 June to $\sim+20.0^{\circ} \mathrm{C}$ in the beginning of July to $\sim+22.5^{\circ} \mathrm{C}$ in mid-July (Figure 3 ). Consequently,

402 temperatures ranging from $+12.5^{\circ} \mathrm{C}$ to $+22.5^{\circ} \mathrm{C}$ and $\delta^{18} \mathrm{O}_{\text {lakewater }}$ at $0.2 \%$ intervals from the 
403 measured July values for individual years are used. Varves from 2001-2006 were composed

404 of calcite, whereas varves from 2007-2010 were $>75 \%$ aragonite, so Eqs. 2 and 1 were used

405 respectively. In the majority of years, at $\sim+20^{\circ} \mathrm{C}$ and a $\delta^{18} \mathrm{O}_{\text {lakewater value from July, or } 0.2 \% \text { o }}$

406 lower, the measured $\delta^{18} \mathrm{O}_{\text {carbonate }}$ values match the $\delta^{18} \mathrm{O}_{\text {carbonate }}$ predicted from the equations

407 (Figure 9). These temperature and $\delta^{18} \mathrm{O}_{\text {lakewater }}$ values are both representative of conditions

408 around the end of June and the beginning of July, suggesting carbonate precipitation peaks at

409 this time and that $\delta^{18} \mathrm{O}_{\text {carbonate }}$ in the sediment record should reflect $\delta^{18} \mathrm{O}_{\text {lakewater }}$ at these times.

410

$411 \quad$ Figure 9

412

$413 \quad 5.2 \quad$ Inter-annual trends at Nar Gölï

414

415 Nar Gölü experienced a period of falling lake levels between 2000 and 2010. It is possible

416 that this was partly caused by depletion of regional groundwater levels and steepening of the

417 hydraulic gradient north of the lake watershed. The lake may also be recovering from

418 groundwater disturbance due to the drilling of the borehole in 1990. Additionally, climate

419 changes will have had a significant control on water balance through this period. Based on

420 the climate data given in section 4.3, the combination of less precipitation and hotter

421 summers 1997-2008 would have reduced direct precipitation and shallow groundwater inflow

422 and increased water losses through evaporation from the lake surface. The cumulative

423 weighted 8-year P/E index from Niğde reached maximum values in 1997, decreasing to a

424 minimum in 2005-2008 (Figure 5) (matched by the lake level decrease of $\sim 3 \mathrm{~m}$ ) and then rose

425 again in 2009 and 2010 (at which time the lake level stabilised). Whatever the precise causes

426 of the observed lake-level fall (climate and/or pumping of groundwater), the results show that

427 this is reflected in the monitoring and sedimentary record. There are close parallels with 
428 monitoring studies of lakes Mogan and Eymir on the edge of Ankara (Özen et al., 2010).

429 Although these two lakes have been impacted by nutrient pollution and other human actions, 430 they also showed a very clear hydrological response to the same drought conditions recorded 431 at Nar Gölü, from 2004 to 2007, demonstrating a region-wide hydrological response of lake 432 ecosystems to climatic forcing. Our monitoring shows that decreasing water levels of Nar

433 Gölü between 2000 and 2010 were associated with an increase in $\delta^{18} \mathrm{O}_{\text {lakewater }}$ of $\sim 3 \%$ o and in 434 lake surface water EC of $\sim 600 \mu \mathrm{Scm}^{-1}$ (although more EC measurements in the early 2000s 435 would have been required to clarify that there was indeed a period of low EC at this time). 436 Changes in $\delta^{18} \mathrm{O}_{\text {lakewater }}$ are generally driven by changes in $\delta^{18} \mathrm{O}_{\text {precipitation }}$ and/or

437 modification by evaporation within-lake (Leng and Marshall, 2004 and references therein).

438 Here, $\delta^{18} \mathrm{O}_{\text {spring }}$ values are seen to represent local precipitation since they plot on the meteoric 439 water line (Figure 2) and have remained more or less stable over the study period (Table 1), 440 indicating that changes in $\delta^{18} \mathrm{O}_{\text {precipitation }}$ could not be driving the increase in $\delta^{18} \mathrm{O}_{\text {lakewater. }}$.

441 Rather, the strong relationship between $\delta^{18} \mathrm{O}_{\text {lakewater }}$ and lake depth (Figure 5) adds weight to 442 the suggestion that $\delta^{18} \mathrm{O}_{\text {lakewater }}$ trends are driven by changing water balance (e.g. Jones et al., 443 2005).

444 To observe how this signal has been transferred to the palaeo-limnological record, 445 isotopic, geochemical and biological proxies have been analysed for individual lake varves 446 from short sediment cores. There is a good match between changes in hydro-climate, lake 447 depth and the $\delta^{18} \mathrm{O}_{\text {carbonate }}$ record (Figure 5). Equilibrium precipitation and a lack of diagenetic 448 effects have already been demonstrated (section 5.1). Assuming there is always equilibrium 449 precipitation and diagenesis never significantly alters the isotope signal, two factors should $450 \operatorname{control} \delta^{18} \mathrm{O}_{\text {carbonate }}: \delta^{18} \mathrm{O}_{\text {lakewater }}$ and the temperature-dependent carbonate-water fractionation

451 effect. The very strong, positive relationship between $\delta^{18} \mathrm{O}_{\text {lakewater }}$ and $\delta^{18} \mathrm{O}_{\text {carbonate }}(r=+0.99$, $452 \mathrm{n}=8, p<0.005)$ and the weighting of carbonate precipitation to the summer months indicates 


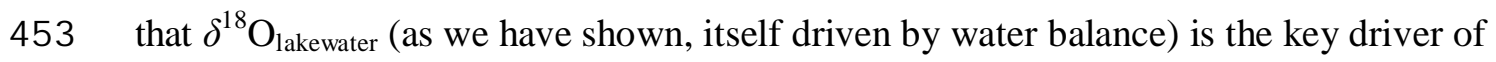

$454 \delta^{18} \mathrm{O}_{\text {carbonate. }}$

455 There is evidence of an increase in the summer $\mathrm{Mg} / \mathrm{Ca}$ ratio (Table 2), caused by 456 concentration of magnesium due to evaporation and loss of calcium by precipitation of 457 calcium carbonate (Kelts and Talbot, 1990). There was also a shift in the sediment core from 458 calcite precipitation 1997-2006 to mostly aragonite precipitation 2007-2010. Shifts from

459 calcite to aragonite precipitation may be associated with an increase in the $\mathrm{Mg} / \mathrm{Ca}$ ratio of 460 lake water (Müller et al., 1972; Kelts and Hsü, 1978; Ito, 2001), which favours the precipitation of aragonite over calcite (Berner, 1975; De Choudens-Sanchez and Gonzalez, 2009). At Nar Gölü, the recent switch from calcite to aragonite precipitation and the decrease

463 in the $\mathrm{Ca} / \mathrm{Sr}$ ratio (Figure 5) (Tesoriero and Pankow, 1996) supports the interpretation of 464 these proxies as indicative of a negative hydrological trend. Of note, in comparison to the $465 \delta^{18} \mathrm{O}_{\text {carbonate }}$ trends, there is a threshold response from calcite to aragonite.

466 Comparison of measured EC with DI-EC shows similar overall trends, but there is an 467 offset in absolute values (Figure 6). The intra-annual data provide a partial explanation as to 468 why DI-EC is lower than measured EC in Nar Gölü. Whereas the EC measurements shown 469 on Figure 6 were taken in July, much of the diatom growth is believed to occur earlier in the 470 year, when EC is substantially lower (Figure 3). The availability of measured EC data

471 unfortunately do not allow us to observe the actual nature of the inferred shift in conductivity

472 post 2006, in terms of timing and rate. Some individual diatom species change earlier than

473 the shift in the DI-EC record, albeit at a gradual rate, for example C. anatolicus. The

474 observed trends in diatom assemblages may indicate a response to controls other than

475 conductivity and/or salinity, for example changing lake habitat availability (Barker et al.,

476 1994), and care must be taken when using such biological indicators as a proxy of mean

477 annual conductivity (Juggins, 2013). An increase in marginal environments as lake-levels 
478 fall, for example, may explain increases in periphytic taxa such as A. minutissimum

479 (Woodbridge and Roberts, 2011) and/or a change in seasonal mixing regime during the 480 period of lake-level decrease.

481 In summary, there is a correspondence through the 2000s between measured

482 hydrological parameters on the one hand, and lake chemistry and hydro-biology

483 reconstructed from sedimentary proxy data on the other, although parameters show different

484 responses in terms of type (threshold vs. linear) and sensitivity to change. The P/E ratio was

485 highest (most positive water balance) in 1997, with a marked decline after 2003, ending in

486 2008. The lake-level decline ended in 2010. $\delta^{18} \mathrm{O}_{\text {lakewater }}$ and EC show a rise through the

4872000 s with the former stabilising after 2008 in a similar way to the P/E trend (Figure 5). The

488 shift to higher $\delta^{18} \mathrm{O}_{\text {carbonate }}$ from 2000 also starts to slow after 2008. In contrast, carbonate

489 mineralogy and $\mathrm{Ca} / \mathrm{Sr}$ data show threshold responses and DI-EC shows a less clear trend than

$490 \delta^{18} \mathrm{O}_{\text {carbonate, }}$ although changes are more linear when looking at the abundance of individual

491 diatom species.

492

$4935.3 \quad$ Implications for the interpretation of palaeo-records

494

495 Monitoring work as described here is primarily carried out to improve interpretations of long-

496 term palaeo-hydrological records, such as those previously published from this site (Jones et

497 al., 2006; Woodbridge and Roberts, 2011; Dean et al., 2013). In the case of Nar Gölü, the

498 magnitude of the variability in $\delta^{18} \mathrm{O}_{\text {carbonate }}$ and DI-EC recorded through the monitoring period

499 covers much of the variability seen in $\delta^{18} \mathrm{O}_{\text {carbonate }}$ and DI-EC over the last 1,720 years (shown

500 by the shaded boxes on Figure 10).

501

502 Figure 10 
504 Viewing the monitored changes within the longer-term context of the palaeo-record

505 highlights a number of points of interest. There is a relative lack of response in the DI-EC

506 record compared to $\delta^{18} \mathrm{O}_{\text {carbonate }}$ data (Jones et al., 2006) through most of the record. In

507 contrast, changes in diatom assemblages, reflected by the diatom zonation (derived by

508 stratigraphically-constrained cluster analysis; Woodbridge and Roberts, 2011), do correlate

509 well with shifts in $\delta^{18} \mathrm{O}$ (Figure 10), with Achnanthidium minutissimum increasing at

510 AD1400, showing the same relationship as observed through the monitoring period. This

511 shift in diatom species does not significantly alter the DI-EC reconstruction, potentially

512 because A. minutissimum and other non-planktonic species respond to habitat availability as

513 well as to EC in this system. The strength of the DI-EC reconstruction is also reduced by the

514 lack of environmental knowledge about Clipeoparvus anatolicus, a dominant species in the

515 assemblage, but a newly described species from Nar Gölü (Woodbridge et al., 2010), which

516 is not included in the modern training set. The ordination of diatom taxa via DCA provides a

517 summary representation of species changes at Nar Gölü. The DCA axis 1 score does,

518 however, show a pattern similar to the DI-EC, only showing significant changes around

519 AD500 as Cyclotella meneghiniana and Staurosira construens var venter are replaced by an

520 assemblage dominated by N. paleacea (Woodbridge and Roberts, 2011). DCA axis 2 records

521 change around AD1400 as A. minutissimum and Synedra acus become more dominant in the

522 record (Figure 10).

523 The lake monitoring described here, in conjunction with a multiproxy record of past

524 hydro-climatic change, substantially reduces the possibility of interpretive errors of the

525 palaeo-record. Our monitoring data, and the discussion of the DI-EC here and in Woodbridge

526 and Roberts (2011), suggest that care is needed when using the DI-EC reconstruction in terms

527 of absolute values of conductivity change. By superimposing the range of variability in 
528 different proxies during the period of lake monitoring with that shown in the palaeo-record, it

529 is also possible to identify which periods in the past potentially lack a modern analogue. The

530 similarity between the shifts in the monitoring period and at AD1400 now allows partial

531 quantification of this change. Although there is no direct analogue of the changes at AD500,

532 the record points to a lake-level increase, associated with a shift in the diatom assemblage,

533 with a magnitude that was larger than changes in the reverse direction AD1400 (Figure 10)

534 and that observed in recent times.

535

536 6. Conclusions

537

538 Using the example of Nar Gölü, we have highlighted how monitoring data can be used to test

539 assumptions and to help produce more robust interpretations of the sediment record, although

540 our findings could be tested further by a larger dataset based on multiple annual

541 measurements. Due to the varved nature of the sediments, it has been possible to compare

$542 \delta^{18} \mathrm{O}$ from core sediments to $\delta^{18} \mathrm{O}$ from trap sediments to $\delta^{18} \mathrm{O}$ from water samples from

543 specific years. While Nar Gölü is a non-outlet lake in a semi-arid region and therefore

$544 \delta^{18} \mathrm{O}_{\text {lakewater }}$ is likely to reflect water balance, monitoring is still vital to test this and to assess

545 the response rate and magnitude of the different palaeo-hydrological proxies. The strong

546 relationship between $\delta^{18} \mathrm{O}_{\text {carbonate }}, \delta^{18} \mathrm{O}_{\text {lakewater }}$ and changes in lake depth, and the apparent

547 equilibrium precipitation of the carbonate, indicate that $\delta^{18} \mathrm{O}_{\text {carbonate }}$ at Nar Gölü is likely to

548 provide a reliable indicator of regional hydro-climatic change over longer time periods.

549 Based on modern response times, $\delta^{18} \mathrm{O}$ can offer a hydro-climatic signal of decadal-scale

550 resolution at this lake. Other palaeo-hydrological proxies, including DI-EC and carbonate

551 mineralogy, exhibit more complex or less easily quantified responses to changes in water

552 balance, with a less linear response between climate change and proxy records. However, 
553 these proxies offer complementary data, which provide a cross-check when conducting 554 palaeo-hydrological reconstructions.

555 In the 'natural laboratory' that is offered by Nar Gölü, conditions make it possible to 556 critically test the chain of connection from present to past, and from the lake waters to the 557 palaeo-record. Our analyses link together the timescales of monitoring and observation on the 558 one hand, with those of palaeo-hydrological reconstruction on the other. The conclusions 559 drawn from this study are site-specific, and in other lakes other proxies may exhibit the 560 clearest relationship to hydro-climate. Nonetheless, our analysis does provide a critical test of 561 causal relationships that are often assumed, rather than demonstrated, to be the case.

562

\section{Acknowledgements}

564

565 JRD, MDJ and NR prepared the manuscript, with intellectual input from all authors. WJE,

566 HK, NR, JRD, MDJ, SLA and JW conducted the fieldwork in Turkey. MJL oversaw the

567 isotope work and assisted JRD, MDJ and SEM in the analysis and interpretation of these

568 results. SLA conducted the XRF analysis. JW conducted the diatom assemblage analysis and

569 interpretation. Field visits to Nar Gölü have been supported by National Geographic and

570 British Institute at Ankara grants to NR and WJE, and by Turkey's MTA Institute. Isotope

571 work was financed by NIGFSC grants IP/968/0507, IP/1198/1110 and IP/1237/0511 to MDJ.

572 JRD was funded by NERC PhD Studentship NE/I528477/1 (2010-2014). All authors have

573 approved the final manuscript.

574

575 We would also like to thank those other collaborators who have contributed to field work

576 over the past decade: Ersin Ateş, Çetin Şenkul, Gwyn Jones, Ryan Smith, Fabien Arnaud,

577 Emmanuel Malet, Ceran Şekeryapan, Mustafa Karabıyıkoğlu, Catherine Kuzucuoğlu, Ann 
578 England, Damase Mouralis and Jane Reed. The local community provided invaluable

579 samples that allowed us to investigate the intra-annual variability. Murat Türkeş supplied the

580 meteorological data and David Hannah assisted with the Tinytag data analysis. Carol

581 Arrowsmith, Christopher Kendrick, Hilary Sloane, Teresa Needham and Graham Morris all

582 assisted with laboratory work. Thanks to David Ryves for loan of the Van Dorn bottle,

583 Applied Acoustics Ltd for use of the seismic survey equipment and the Turkish Ministry of

584 Environment and Forests for research permission. Finally, we are very grateful to Jane Reed

585 and Emi Ito for thorough reviews of our manuscript. This paper is published with the

586 permission of the Executive Director of the British Geological Survey.

587

\section{References}

589

590 Akbaşlı, A (1992) Nigde-Sofular Acigol (Narligol) sicak su sondajlari (Nar-1, MTA-1, MTA-

591 2, MTA-3) kutu bitirme raporu. MTA Rapor Arsivi no 9407, Ankara

592 Barker, PA, Roberts, N, Lamb, HF, van der Kaars, S, Benkaddour, A (1994) Interpretation of

593 lake-level change from diatom life form in Lake Sidi Ali, Morocco. J Paleolimnol 12:

$594 \quad 223-234$

595 Battarbee, RW, Jones, VJ, Flower, RJ, Cameron, NG, Bennion, H (2001) Cht 8: Diatoms. In:

596 Smol, J (ed) (2001) Tracking Environmental Change Using Lake Sediments, Vol 3:

597 Terrestrial, Algal and Siliceous Indicators. Kluwer Academic Publishers, Netherlands.

$598 \longrightarrow 155-202$

599 Berner, RA (1975) The role of magnesium in the crystal growth of calcite and aragonite from

600 sea water. Geochim Cosmochim Ac 39: 489-504 
601 De Choudens-Sanchez, V, Gonzalez, LA (2009) Calcite and aragonite precipitation under

602 controlled instantaneous supersaturation: elucidating the role of $\mathrm{CaCO}_{3}$ saturation state

603 and Mg/Ca Ratio on calcium carbonate polymorphism. J Sediment Res 79: 363-376

604 Dean, JR, Jones, MD, Leng, MJ, Sloane, HJ, Roberts, CN, Woodbridge, J, Swann, GEA,

605 Metcalfe, SE, Eastwood, WJ, Yiğitbaşıŏlu, H (2013) Palaeo-seasonality of the last two

606 millennia reconstructed from the oxygen isotope composition of carbonates and diatom

607 silica from Nar Gölü, central Turkey. Quaternary Sci Rev 66: 35-44

608 Fritz, SC (2008) Deciphering climatic history from lake sediments. J Paleolimnol 39: 5-16

609 Fritz SC, Cumming BF, Gasse F, Laird K (2010) Diatoms as indicators of hydrologic and

610 climatic change in saline lakes. In: Stoermer EF, Smol JP (eds) The Diatoms:

611 Applications for the Environmental and Earth Sciences. Cambridge University Press,

612 Cambridge, pp 186-208

613 Fronval, T, Jensen, NB, Buchardt, B (1995) Oxygen-isotope disequilibrium precipitation of

614 calcite in Lake Arreso, Denmark. Geology 23: 463-466

615 Gevrek, A, Kazanci, N (2000) A Pleistocene, pyroclastic-poor maar from central Anatolia,

616 Turkey: influence of a local fault on a phreatomagmatic eruption. J Volcanol Geotherm

$617 \quad$ Res 95: 309-317

618 Glew, JR, Smol, JP, Last, WM (2001) Sediment core collection and extrusion. In: Last, WM,

619 Smol, JP (eds) Tracking Environmental Change Using Lake Sediments. Volume 1: Basin

620 Analysis, Coring and Chronological Techniques. Kluwer, Dordrecht, pp 73-105

621 Hardy, R, Tucker, M (1988) X-ray powder diffraction of sediment. In: Tucker M (ed)

622 Techniques in Sedimentology. Blackwell, Oxford, pp 191-228

623 Hays, PD, Grossman, EL (1991) Oxygen isotopes in meteoric calcite cements as indicators of

624 continental paleoclimate. Geology 19: 441-444 
625 Hem, JD (1970) Study and Interpretation of the Chemical Characteristics of Natural Water.

$626 \quad$ United States Government Printing Office, Washington

627 Hollander, DJ, McKenzie, JA (1991) $\mathrm{CO}_{2}$ control on carbon-isotope fractionation during

628 aqueous photosynthesis: a paleo- $\mathrm{pCO}_{2}$ barometer. Geology 19: 929-932

629 IAEA/WMO (2014) Global Network of Isotopes in Precipitation. Available:

630 http://www.iaea.org/water Accessed: 4 January 2014

631 Ito, E (2001) Application of stable isotope techniques to inorganic and biogenic carbonates.

632 In: Last, WM, Smol, JP (eds) Tracking Environmental Change Using Lake Sediments.

633 Volume 2: Physical and Geochemical Methods. Kluwer, Dordrecht, pp 351-371

634 Jones, MD, Leng, MJ, Roberts, CN, Turkes, M, Moyeed, R (2005) A coupled calibration and

635 modelling approach to the understanding of dry-land lake oxygen isotope records. J

$636 \quad$ Paleolimnol 34: 391-411

637 Jones, MD, Roberts, CN, Leng, MJ, Turkes, M (2006) A high-resolution late Holocene lake

638 isotope record from Turkey and links to North Atlantic and monsoon climate. Geology

$639 \quad 34: 361-364$

640 Juggins, S (2003) C2 version 1.3: software for ecological and palaeoecological data analysis

641 and visulisation. Departmeent of Geography, University of Newcastle.

642 Juggins, S (2013) Quantitative reconstructions in palaeolimnology: new paradigm or sick

643 science? Quaternary Science Reviews 64: 20-32

644 Juggins, S (2014) European Diatom Database Online. Available:

645 http://craticula.ncl.ac.uk/Eddi/jsp/index.jsp Accessed: 1 June 2014

646 Kelts, K, Hsü, J (1978) Freshwater carbonate sedimentation. In: Lerman, A (ed) Lakes:

647 Geology, Chemistry and Physics. Springer-Verlag, New York, pp 295-323 
648 Kelts, K, Talbot, M (1990) Lacustrine carbonates as geochemical archives of environmental

649 change and biotic/abiotic interations. In: Tilzer, M, Serruya, C (eds) Large Lakes:

650 Ecological Structure and Function. Springer-Verlag, Berlin, pp 288-315

651 Kim, ST, O'Neil, JR, Hillaire-Marcel, C, Mucci, A (2007) Oxygen isotope fractionation

652 between synthetic aragonite and water: influence of temperature and $\mathrm{Mg} 2+$

653 concentration. Geochim Cosmochim Ac 71: 4704-4715

654 Kutiel, H, Türkeş, M (2005) New evidence for the role of the North Sea-Caspian Pattern on

655 the temperature and precipitation regimes in continental Central Turkey. Geogr Ann A

$656 \quad 87 \mathrm{~A}: 501-513$

657 Langbein, WB (1961) Salinity and hydrology of closed lakes. United States Geological

658 Survey professional paper. 412. US Government Printing Office, Washington

659 Leng, MJ, Marshall, JD (2004) Palaeoclimate interpretation of stable isotope data from lake

660 sediment archives. Quaternary Sci Rev 23: 811-831

661 Leng, MJ, Roberts, N, Reed, JM, Sloane, HJ (1999) Late Quaternary palaeohydrology of the

662 Konya Basin, Turkey, based on isotope studies of modern hydrology and lacustrine

663 carbonates. J Paleolimnol 22: 187-207.

664 Lepŝ, J, Ŝmilauert, P (2003) Multivariate Analysis of Ecological Data Using CANOCO.

665 Cambridge University Press, Cambridge

666 Magny, M (2006) Holocene fluctuations of lake levels in west-central Europe: methods of

667 reconstruction, regional pattern, palaeoclimatic significance and forcing factors.

668 Encyclopedia of Quaternary Geology, Elsevier, Vol. 2, pp 1389-1399

669 Müller, G. Forstner, U, Irion, G (1972) Formation and diagenesis of inorganic Ca-Mg

670 carbonates in lacustrine environment. Naturwissenschaften 59: 158-164

671 Ojala, AEK, Francus, P, Zolitschka, B, Besonen, M, Lamoureux, SF (2012) Characteristics of

672 sedimentary varve chronologies - a review. Quaternary Sci Rev 43: 45-60 
673 Özen, A, Karapınar, B, Kucuk, I, Jeppeson, E, Beklioğlu, M (2010) Drought-induced changes

674 in nutrient concentrations and retention in two shallow Mediterranean lakes subjected to

675 different degrees of management. Hydrobiologia 646: 61-72

676 Reed, JM, Mesquita-Joanes, F, Griffiths, HI (2012) Multi-indicator conductivity transfer

677 functions for Quaternary palaeoclimate reconstruction. J Paleolimnol 47: 251-575

678 Reimer, A, Landmann, G, Kempe, S (2009) Lake Van, eastern Anatolia, hydrochemistry and 679 history. Aquat Geochem 15: 195-222

680 Romero-Viana, L, Julia, R, Camacho, A, Vicente, E, Miracle, MR (2008) Climate signal in

681 varve thickness: Lake La Cruz (Spain), a case study. J Paleolimnol 40: 703-714

682 Saros, JE (2009) Integrating neo- and palaeolimnological approaches to refine interpretations

683 of environmental change. J Paleolimnol 41: 243-252

684 Smith, R (2010) A Geophysical Survey of Nar Golu, Cappadocia, Turkey. MSc thesis,

685 Plymouth University.

686 Sondi, I, Juracic, M (2010) Whiting events and the formation of aragonite in Mediterranean

687 karstic marine lakes: new evidence on its biologically induced inorganic origin.

$688 \quad$ Sedimentology 57:85-95

689 Teranes, JL, Bernasconi, SM (2000) The record of nitrate utilization and productivity

690 limitation provided by delta N-15 values in lake organic matter - a study of sediment trap

691 and core sediments from Baldeggersee, Switzerland. Limnol Oceanogra 45: 801-813

692 Teranes, JL, McKenzie, JA, Bernasconi, SM, Lotter, AF, Sturm, M (1999) A study of oxygen

693 isotopic fractionation during bio-induced calcite precipitation in eutrophic Baldeggersee,

694 Switzerland. Geochim Cosmochim Ac 63: 1981-1989

695 Tesoriero, AJ, Pankow, JF (1996) Solid solution partitioning of $\mathrm{Sr}^{2+}, \mathrm{Ba}^{2+}$, and $\mathrm{Cd}^{2+}$ to

696 calcite. Geochim Cosmochim Ac 60: 1053-1063 
697 Tian, J, Nelson, D, Hu, F (2011) How well do sediment indicators record past climate? An

698 evaluation using annually laminated sediments. J Paleolimnol 45: 73-84

699 Van Dorn, WG (1956) Large-volume water samplers. Transactions of the American

$700 \quad$ Geophysical Union 37: 682-684

701 Viehberg, FA, Ulgen, UB, Damci, E, Franz, SO, On, SA, Roeser, PA, Cagatay, MN, Litt, T,

702 Melles, M (2012) Seasonal hydrochemical changes and spatial sedimentological

703 variations in Lake Iznik (NW Turkey). Quatern Int 274:102-111

704 Woodbridge, J, Roberts, N (2010) Linking neo- and palaeolimnology: a case study using

$705 \quad$ crater lake diatoms from central Turkey. J Paleolimnol 44: 855-871

706 Woodbridge, J, Roberts, N, Cox, EJ (2010) Morphology and ecology of a new centric diatom

707 from Cappadocia (central Turkey). Diatom Research 25: 195-212

708 Woodbridge, J, Roberts, N (2011) Late Holocene climate of the Eastern Mediterranean

709 inferred from diatom analysis of annually-laminated lake sediments. Quaternary Sci Rev

$710 \quad 30: 3381-3392$

711 Yiğitbaşıŏlu, H, Dean, JR, Eastwood, WJ, Roberts, N, Jones, MD, Leng, MJ, Türkeş, M (in

712 press) A 600 year-long drought index for central Anatolia. MedCLIVAR Conference 2014

713 extended abstract

714

715

716

717

718

719

720

721 


\section{Tables}

\section{3}

724 Table $1 \delta^{18} \mathrm{O}$ from lake surface waters and the upper spring in the catchment, and $\mathrm{EC}$ and $\mathrm{pH}$

725 values from surface lake waters

\begin{tabular}{|c|c|c|c|c|c|}
\hline & $\begin{array}{l}\delta^{18} \mathrm{O}_{\text {lakewater }} \\
\text { surface centre } \\
\% \text { VSMOW }\end{array}$ & $\begin{array}{l}\delta^{18} O_{\text {lakewater }} \\
\text { surface edge } \\
\% \text { VSMOW }\end{array}$ & $\begin{array}{l}\delta^{18} \mathrm{O} \\
\text { upper spring } \\
\% \circ \text { VSMOW }\end{array}$ & $\begin{array}{l}\text { EC } \\
\mu \mathrm{Scm}^{-1}\end{array}$ & $\mathrm{pH}$ \\
\hline Mar. 1997 & & -3.20 & & & \\
\hline Aug. 1999 & & -2.95 & & 2500 & 7.4 \\
\hline July 2000 & & -3.22 & & & \\
\hline July 2001 & -2.64 & & -10.55 & 3300 & 7.9 \\
\hline Mar. 2002 & & -3.14 & -10.63 & & \\
\hline July 2002 & -2.42 & & -10.70 & & \\
\hline July 2003 & -2.50 & & -10.59 & & \\
\hline May 2004 & -2.73 & & & & \\
\hline July 2005 & & -1.88 & & & \\
\hline Sep. 2006 & -0.87 & -1.67 & -10.56 & 3390 & 7.8 \\
\hline July 2008 & -0.57 & & -10.60 & 3380 & 8.3 \\
\hline May 2009 & -1.17 & -1.46 & & 3430 & 8.5 \\
\hline July 2009 & -0.56 & & -10.63 & 3370 & 8.2 \\
\hline July 2010 & -0.24 & & -10.65 & 3430 & 8.5 \\
\hline June 2011 & -0.81 & & -10.55 & 3390 & 8.2 \\
\hline Sep. 2011 & -0.19 & -0.13 & -10.63 & 3540 & 8.1 \\
\hline Feb. 2012 & & -1.25 & & 2190 & 7.3 \\
\hline June 2012 & & -0.75 & & & \\
\hline July 2012 & -0.34 & -0.39 & -10.74 & 3500 & 7.8 \\
\hline April 2013 & -0.90 & & -10.57 & 3720 & 7.7 \\
\hline April 2014 & -1.10 & & -10.61 & 3333 & \\
\hline
\end{tabular}

726 
727 Table 2 Major ion data from surface lake water samples

\begin{tabular}{llllllll}
\hline \multicolumn{7}{c}{ Concentration $\mathbf{~ m e q L}^{-1}$} \\
& SO$_{4}{ }^{-2}$ & $\mathbf{C l}^{-}$ & $\mathbf{N a}^{+}$ & $\mathbf{K}^{+}$ & $\mathbf{~ M g}^{2+}$ & $\mathbf{C a}^{+2}$ & $\mathbf{M g} / \mathbf{C a}$ \\
\hline Aug. 1999 & 3.2 & 27.4 & 16.5 & 3.7 & 8.5 & 3.0 & 2.8 \\
July 2009 & 3.6 & 20.1 & 14.6 & 3.8 & 10.1 & 2.1 & 4.8 \\
July 2010 & 3.8 & 22.7 & 16.2 & 3.6 & 15.4 & 1.0 & 15.4 \\
June 2011 & 2.9 & 20.2 & 13.7 & 4.0 & 8.8 & 2.2 & 4.0 \\
Sep. 2011 & 4.4 & 22.4 & 19.0 & 3.8 & 9.4 & 3.2 & 2.9 \\
Feb. 2012 & 3.0 & 20.2 & 4.1 & 0.0 & 3.2 & 4.0 & 0.8 \\
July 2012 & 4.1 & 23.9 & 16.9 & 3.8 & 16.5 & 1.2 & 13.8 \\
April 2013 & 3.6 & 20.2 & 19.8 & 3.6 & 7.1 & 3.6 & 2.0 \\
\hline
\end{tabular}

728 


\section{$729 \quad$ Figure captions}

730

731 Figure 1 Nar Gölü catchment, shaded grey, with bathymetric map showing the alluvial fan in

732 the southern part of the lake and the variability in depth. Figure $2 \delta \mathrm{D}-\delta^{18} \mathrm{O}$ plot, with data

733 from the Ankara GNIP station 1964-2009 (IAEA/WMO 2014) defining the meteoric water

734 line. Spring waters plot on the meteoric water line, whereas lake waters plot on a local

735 evaporation line.

736 Figure 3 Intra-annual variability in $\delta^{18} \mathrm{O}, \mathrm{EC}, \mathrm{pH}$ and magnesium and calcium concentrations

737 from water samples taken from the lake edge between June 2011 and July 2012, and data

738 from temperature loggers at $5 \mathrm{~m}$ and $21 \mathrm{~m}$ depth from the same time period (the convergence

739 of the lines in November signifies the thermal mixing of the lake and the divergence in March

740 the stratification of the lake).

741 Figure 4 Depth profiles of isotope and geochemical variables from different times of the year

742 (although note profiles were not all taken in the same year), showing the changes in thermo-,

743 chemo- and iso-clines from spring to summer.

744 Figure $5 \delta^{18} \mathrm{O}_{\text {lakewater }}$ (from July surface water samples), measured EC (from July surface

745 water samples), $\delta^{18} \mathrm{O}_{\text {carbonate }}$ from NAR10 core and sediment traps, XRF-derived $\mathrm{Ca} / \mathrm{Sr}$ ratio

746 (see section 3.2 for details) and \% aragonite vs. calcite from NAR10 core, plotted with

747 changes in maximum lake depth and 8-year cumulative weighted P/E ratio from Niğde (data

748 provided by the Turkish Meteorological Service).

749 Figure 6 Major diatom taxa and DI-EC in NAR06 (Woodbridge and Roberts, 2010) and

750 NAR10 cores (new data), and measured EC (from July surface water samples).

751 Figure 7 Intra-annual variability in $\delta^{18} \mathrm{O}_{\text {carbonate }}$ as recorded in a sediment trap in the lake at 5

752 m depth between summer 2001 and summer 2002. 
753 Figure 8 Sediment trap deployed in April 2013 and collected in April 2014, showing the 754 seasonality of sedimentation in Nar Gölü.

755 Figure 9 Predicted $\delta^{18} \mathrm{O}_{\text {carbonate }}$ values from Eqs. 1 and 2 compared to measured $\delta^{18} \mathrm{O}_{\text {carbonate }}$ 756 from NAR10 core, using a variety of lake surface temperature and $\delta^{18} \mathrm{O}_{\text {lakewater values that }}$ 757 represent conditions in the lake from July back to May.

758 Figure 10 1,720-year records of diatom species (Woodbridge and Roberts, 2011) and

$759 \delta^{18} \mathrm{O}_{\text {carbonate }}($ Jones et al., 2006) from the NAR01/02 cores. The variability in DI-EC and $760 \delta^{18} \mathrm{O}_{\text {carbonate }}$ seen during the monitoring period from the NAR10 core are shown by the shaded 761 boxes. Diatom zones from Woodbridge and Roberts (2011) are shown.

762

763 SI Figure 1 Photographs of Nar Gölü between March and April 2012.

764 SI Figure 2 'White-out' around the edges of Nar Gölü in July 2012, and inset SEM image 765 identifying this as aragonite.

766 


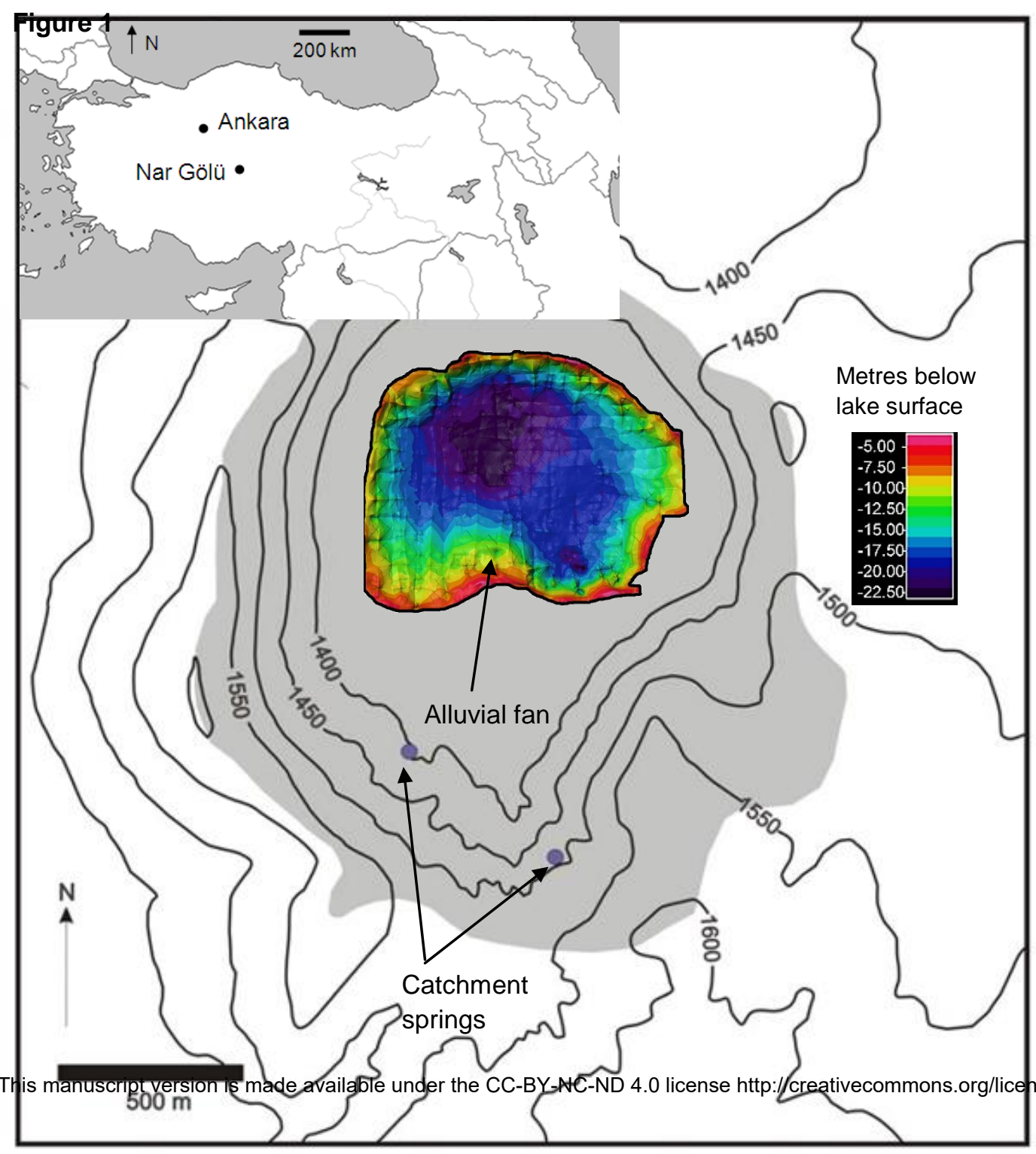


Figurg 2 rkara precipitation

- Lake centre

$\Delta$ Lake edge

- Springs

$\begin{array}{lll}-25 & -20 & -15 \\ \delta^{18} & \%\end{array}$

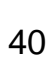

$\times$

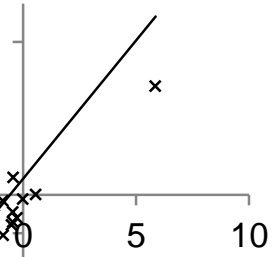

$-10$

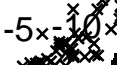

5

10

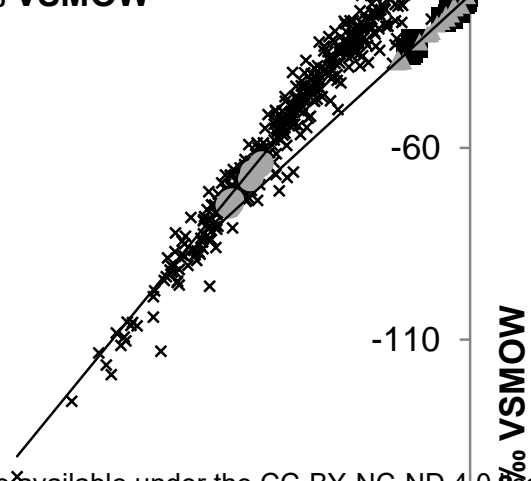

sion is madexavailable under the CC-BY-NC-ND 4.0 icense http://creativ

-160 ดि 

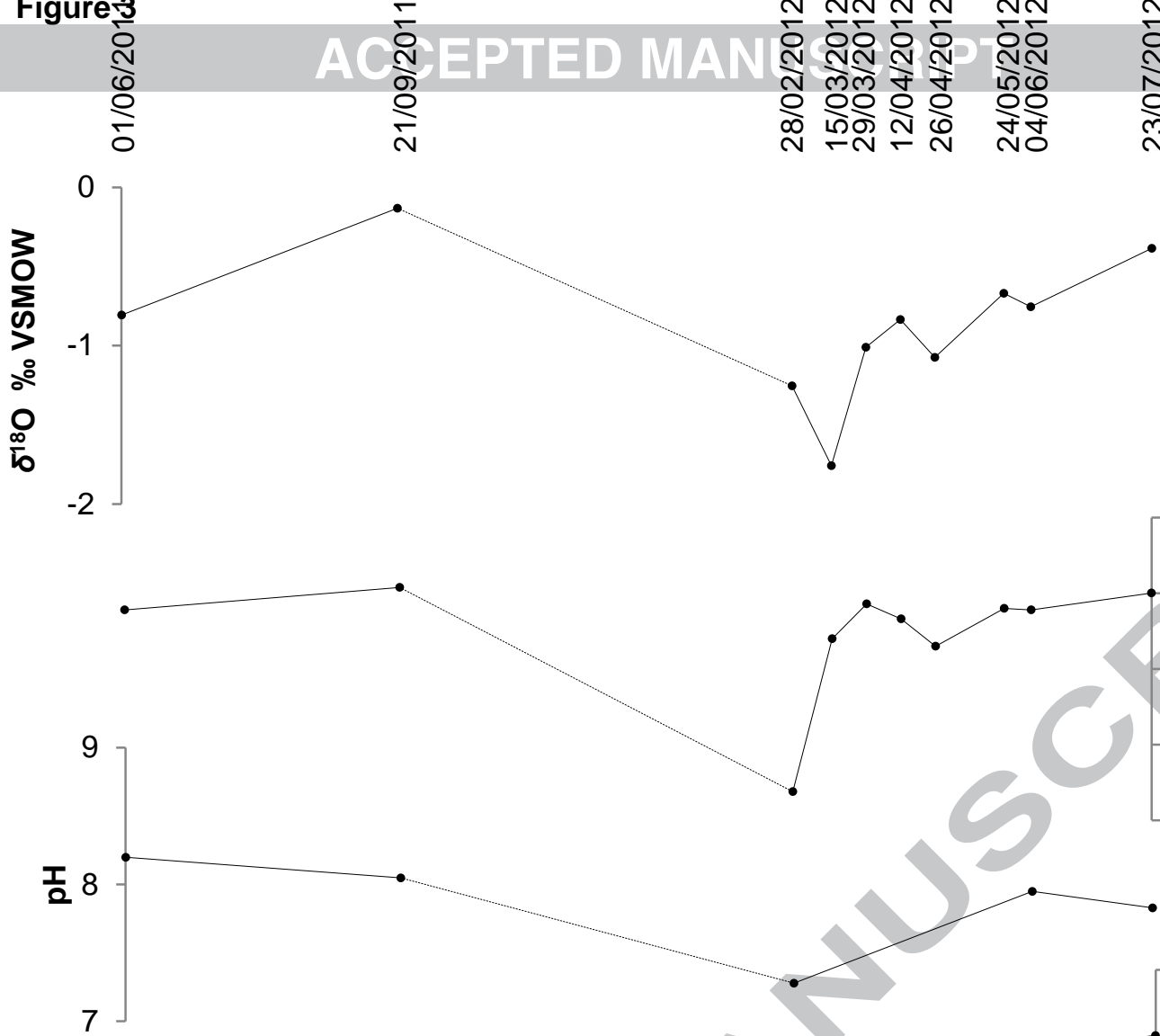

- Magnesium

Calcium

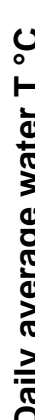

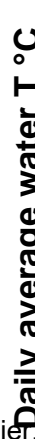

$-5 \mathrm{~m}$

10

5
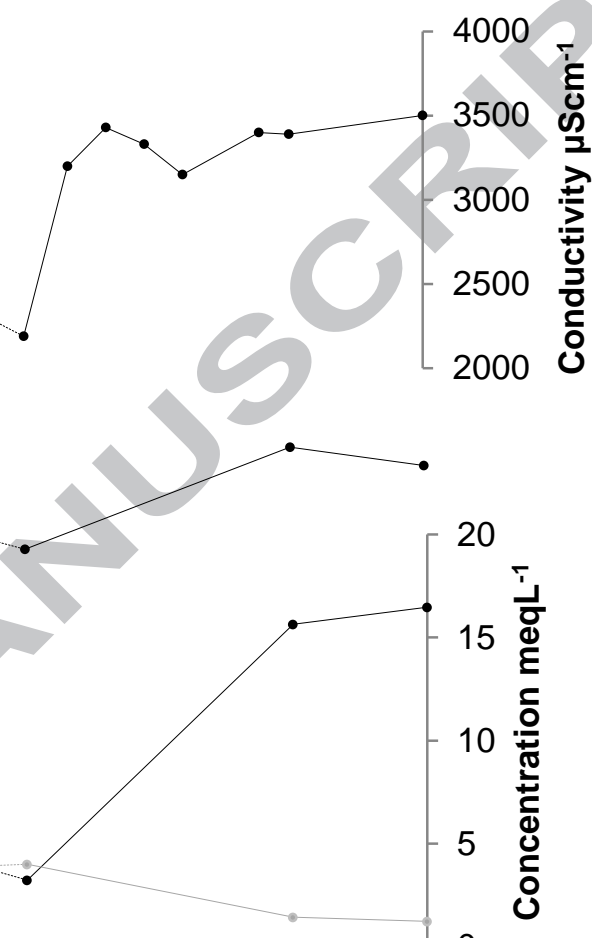

2000

0

Figure

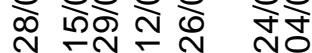
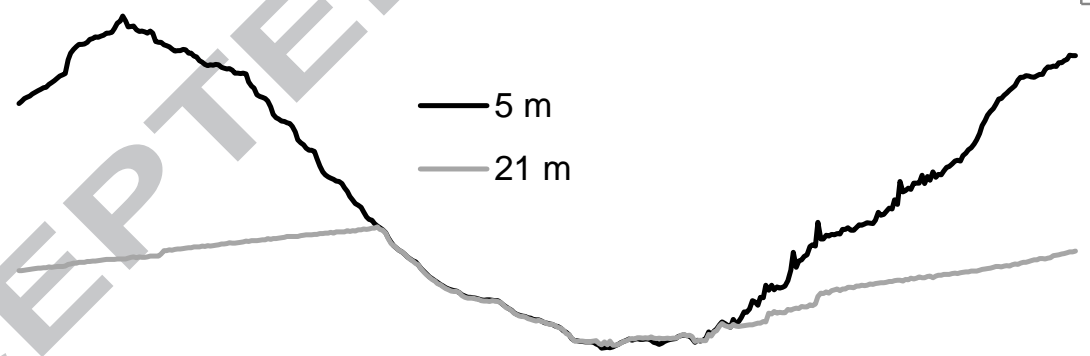

Thi@manuscript version is made available under the CC-BY-NC-ND 4.0 license http://creativecommons.org/licenses 01/06/2011 01/09/2011 02/12/2011 03/03/2012 03/06/2012

\section{Date}




\section{Temperature ${ }^{\circ} \mathrm{C}$}

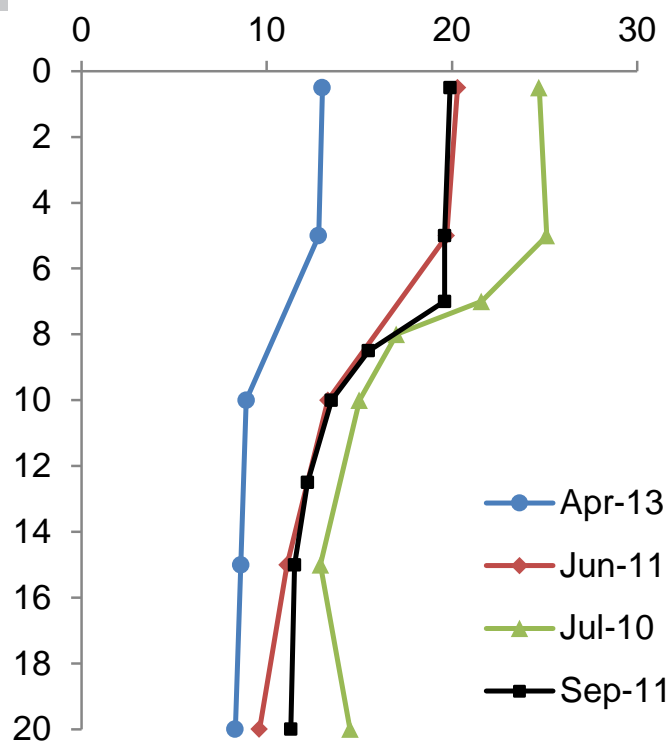

Conductivity $\mu \mathrm{Scm}^{-1}$

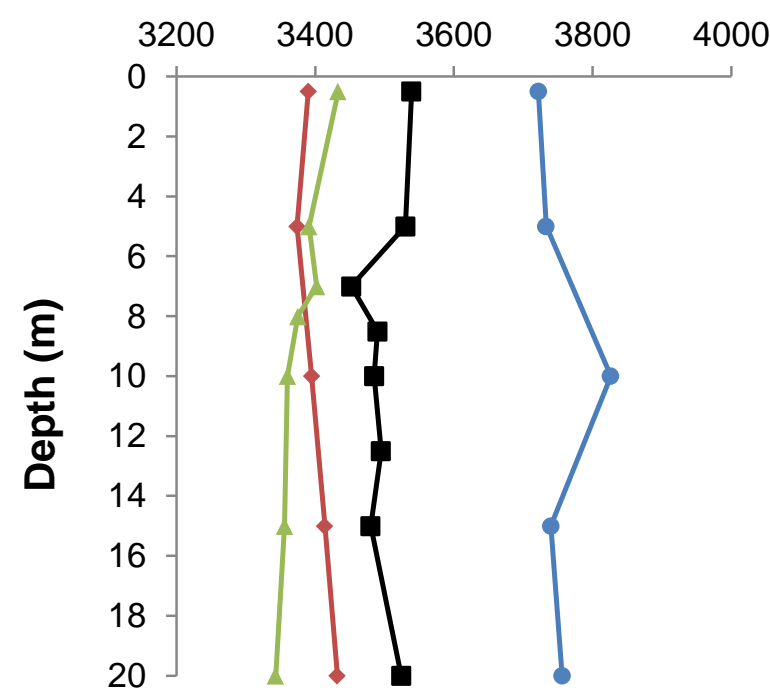

Dissolved oxygen \%

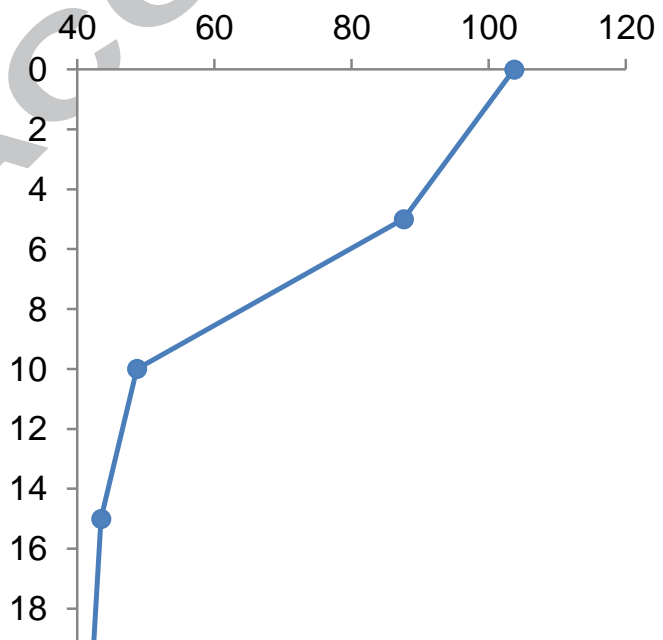

MAN pH

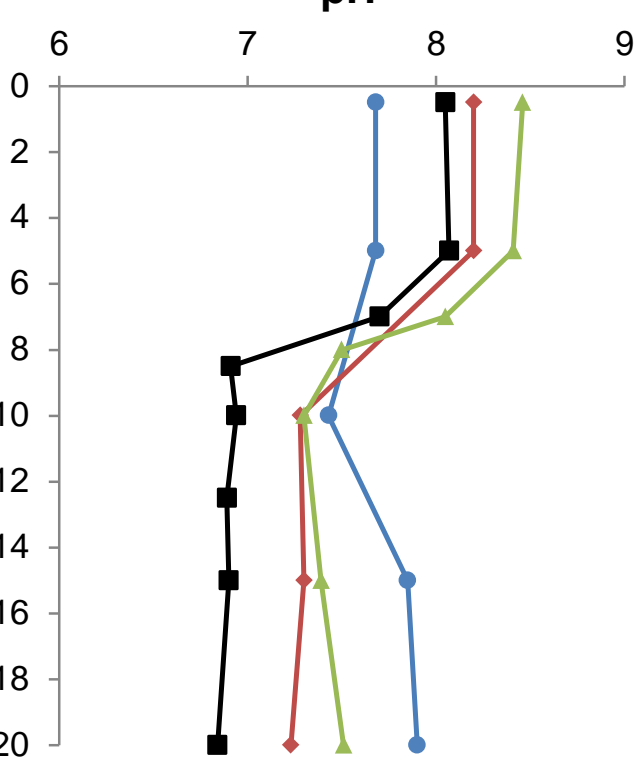

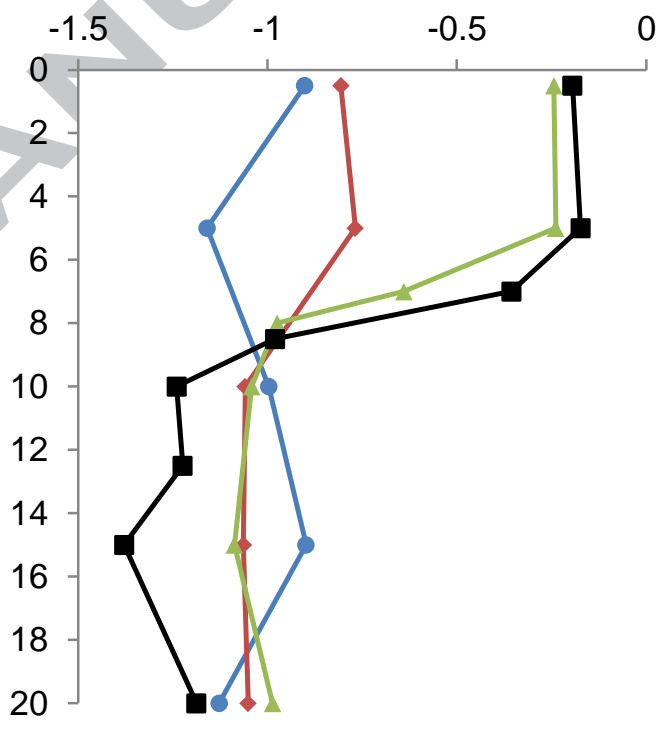

$\mathrm{Mg} / \mathrm{Ca} \mathrm{meqL}^{-1}$

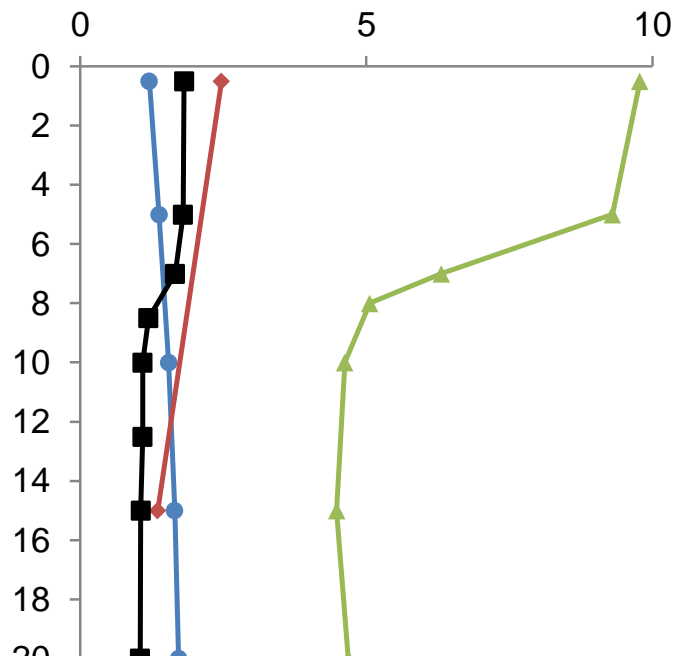



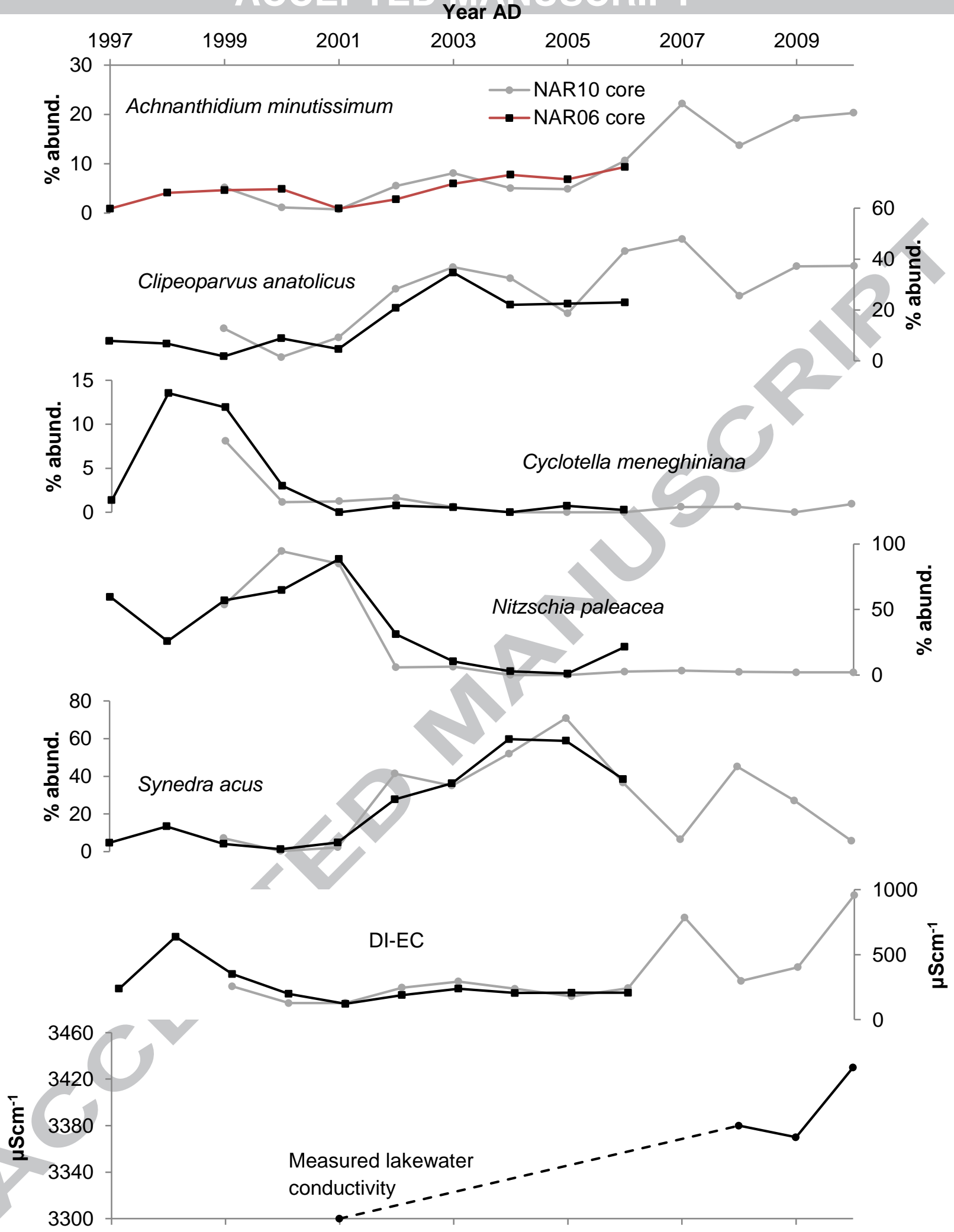

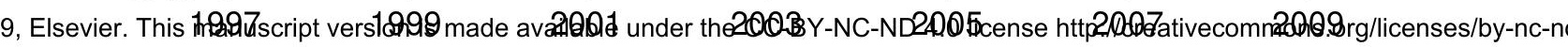


Figure 7

\section{$\delta^{18} O_{\text {carbonate }} \%$ VPDB}

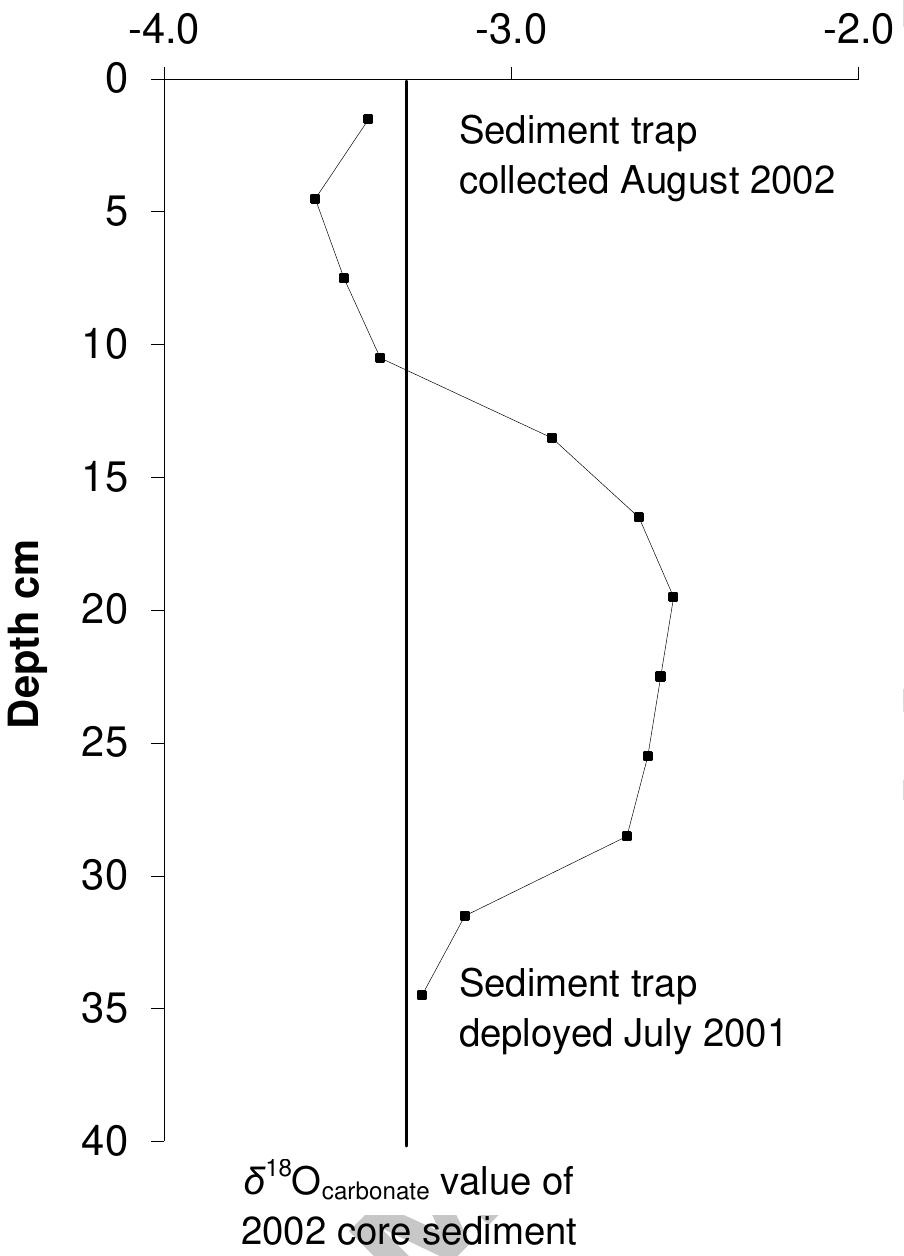

ersion is made available under (h-3.30/00)-NC-ND 4.0 license http://creativec 


\section{Figure 8}

Organic material deposited prior to retrieval in April 2014

Carbonate presumed to have been deposited in summer 2013

Organic material deposited after deployment in April sion is mâde available under the CC-BY-NC-ND 4.0 license http://creativ 
Measured

- Predicted with July $\delta^{18} \mathrm{O}_{l w}-0.2 \%$

- Predicted with July $\delta^{18} \mathrm{O}_{I w}-0.6 \%$
- Predicted with July $\delta^{-18} \mathrm{O}_{\mathrm{lw}}$

- Predicted with July $\delta^{-18} \mathrm{O}_{l w}-0.4 \%$

Predicted with July $\bar{\delta}^{18} \mathrm{O}_{1 w}-0.8 \%$
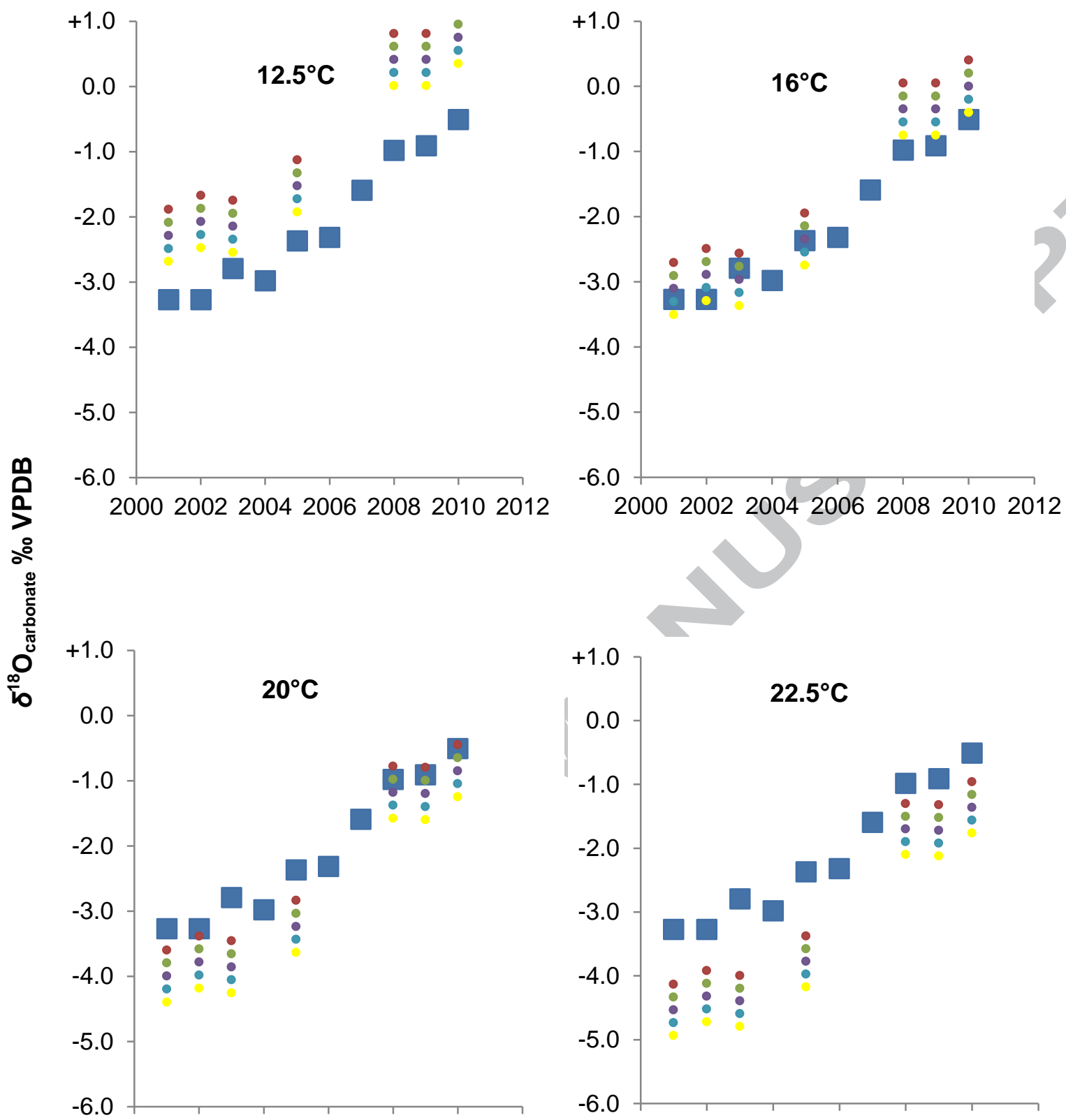

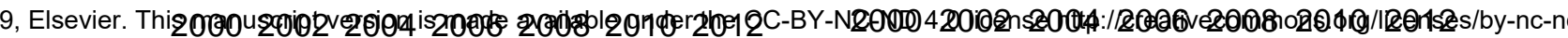




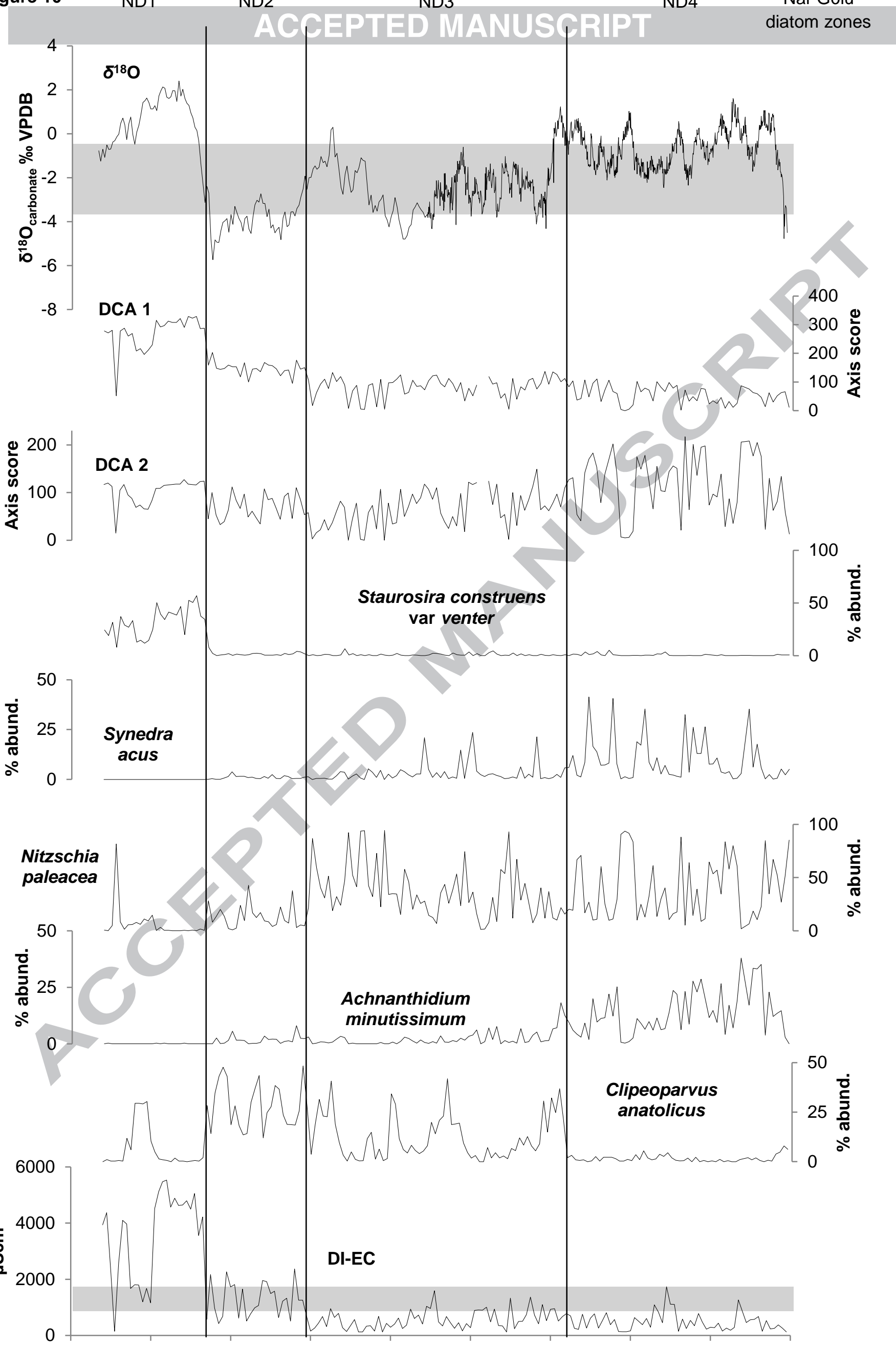

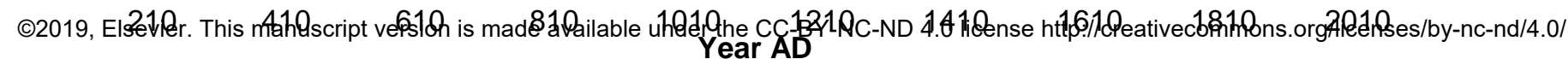




\section{$767 \quad$ Highlights}

768

769 - Study of non-outlet, oligosaline, varve-forming lake in a semi-arid region

770 - Water balance signal in oxygen isotopes tracked from lake waters to sediments

771 - Strong intra- and inter-annual relationships between isotopes and water balance

772 - Diatom-inferred conductivity shows a complex response to change in water balance

773 - Implications of monitoring data for interpretation of palaeo-records

774 